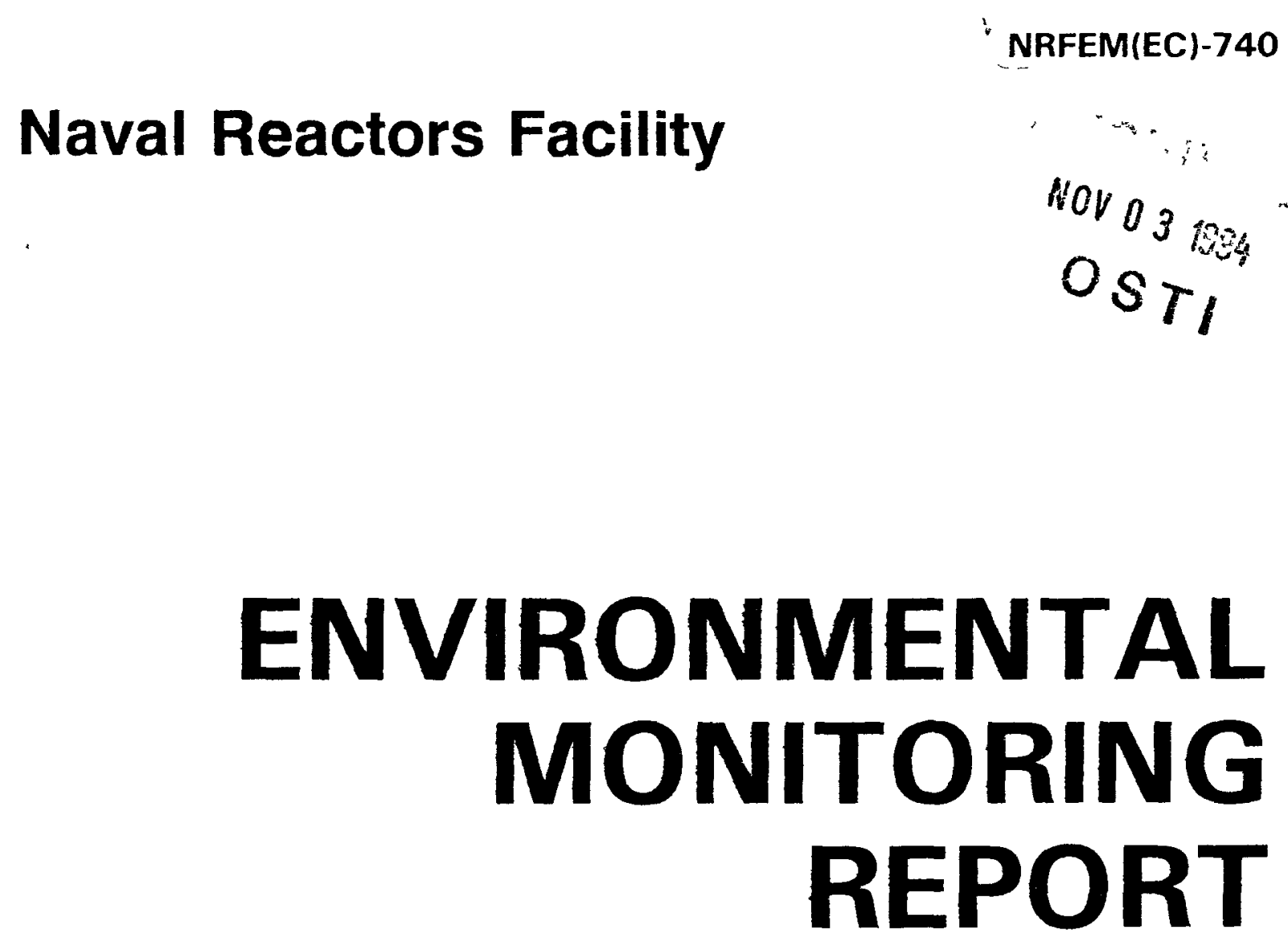

Calendar Year 1993

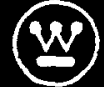

Prepared for the

US Department of Energy

By Westinghouse Electric Corporation Under Contract No DE-AC11-93PN38195

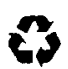

This document printed on recycled paper 


\section{DISCLAIMER}

This report was prepared as an account of work sponsored by an agency of the United States Government. Neither the United States Government nor any agency Thereof, nor any of their employees, makes any warranty, express or implied, or assumes any legal liability or responsibility for the accuracy, completeness, or usefulness of any information, apparatus, product, or process disclosed, or represents that its use would not infringe privately owned rights. Reference herein to any specific commercial product, process, or service by trade name, trademark, manufacturer, or otherwise does not necessarily constitute or imply its endorsement, recommendation, or favoring by the United States Government or any agency thereof. The views and opinions of authors expressed herein do not necessarily state or reflect those of the United States Government or any agency thereof. 


\section{DISCLAIMER}

Portions of this document may be illegible in electronic image products. Images are produced from the best available original document. 


\title{
1993 ENVIRONMENTAL MONITORING REPORT
}

\author{
FOR THE
}

\author{
NAVAL REACTORS FACILITY
}

\section{DISCLAIMER}

This report was prepared as an account of work sponsored by an agency of the United States Government. Neither the United States Government nor any agency thereof, nor any of their employees, makes any warranty, express or implied, or assumes any legal liability or responsibility for the accuracy, completeness, or usefulness of any information, apparatus, product, or process disclosed, or represents that its use would not infringe privately owned rights. Reference herein to any specific commercial product, process, or service by trade name, trademark, manufacturer, or otherwise does not necessarily constitute or imply its endorsement, recommendation, or favoring by the United States Government or any agency thereof. The views and opinions of authors expressed herein do not necessarily state or reflect those of the United States Government or any agency thereof.

\section{PREPARED FOR THE U.S. DEPARTMENT OF ENERGY BY WESTINGHOUSE ELECTRIC CORPORATION NAVAL REACTORS FACILITY}




\section{TABLE OF CONTENTS}

\section{Page}

Table of Contents $\ldots \ldots \ldots \ldots \ldots \ldots \ldots \ldots \ldots \ldots \ldots \ldots \ldots$.

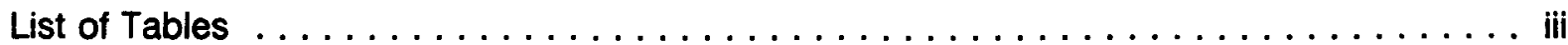

List of Figures $\ldots \ldots \ldots \ldots \ldots \ldots \ldots \ldots \ldots \ldots \ldots \ldots \ldots \ldots \ldots \ldots \ldots \ldots$ iii

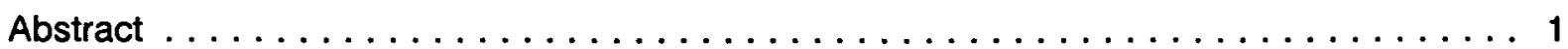

Summary $\ldots \ldots \ldots \ldots \ldots \ldots \ldots \ldots \ldots \ldots \ldots \ldots \ldots \ldots \ldots \ldots \ldots \ldots$

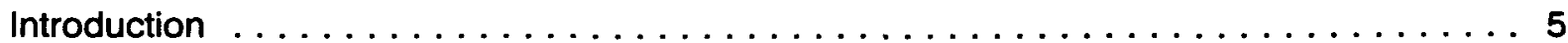

Geological and Demographic Site Description ................... 5

Environmental Monitoring $\ldots \ldots \ldots \ldots \ldots \ldots \ldots \ldots \ldots \ldots$

Program Overview $\ldots \ldots \ldots \ldots \ldots \ldots \ldots \ldots \ldots \ldots \ldots \ldots \ldots, 9$

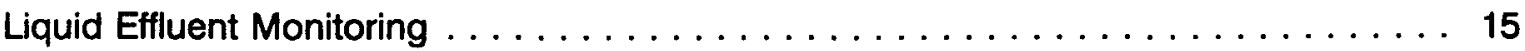

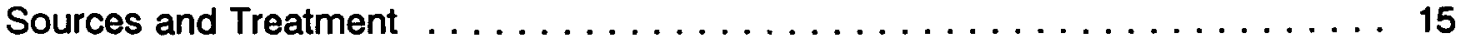

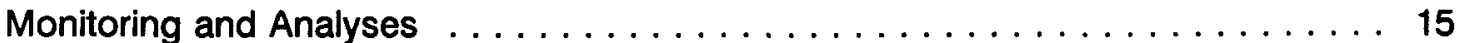

Liquid Effluent Monitoring Conclusions $\ldots \ldots \ldots \ldots \ldots \ldots \ldots \ldots \ldots$

Ground Water Monitoring $\ldots \ldots \ldots \ldots \ldots \ldots \ldots \ldots \ldots \ldots \ldots \ldots \ldots \ldots \ldots$

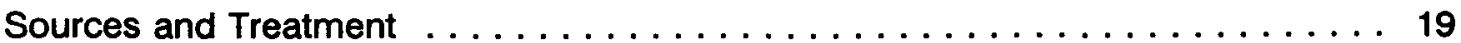

Monitoring and Analyses ......................... 19

Ground Water Monitoring Conclusions $\ldots \ldots \ldots \ldots \ldots \ldots \ldots \ldots \ldots \ldots \ldots$

Airborne Effluent Monitoring $\ldots \ldots \ldots \ldots \ldots \ldots \ldots \ldots \ldots \ldots \ldots \ldots \ldots \ldots$

Sources and Treatment $\ldots \ldots \ldots \ldots \ldots \ldots \ldots \ldots \ldots \ldots \ldots \ldots \ldots \ldots$

Monitoring and Analyses ................................... 27

Airborne Effluent Monitoring Conclusions $\ldots \ldots \ldots \ldots \ldots \ldots \ldots \ldots 29$

Environmental Radiological Monitoring $\ldots \ldots \ldots \ldots \ldots \ldots \ldots \ldots \ldots \ldots \ldots \ldots$

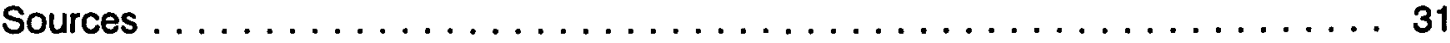

Monitoring and Analyses $\ldots \ldots \ldots \ldots \ldots \ldots \ldots \ldots \ldots \ldots \ldots \ldots \ldots \ldots \ldots \ldots$

Environmental Radiological Monitoring Conclusions .............. 31

Radiation Monitoring $\ldots \ldots \ldots \ldots \ldots \ldots \ldots \ldots \ldots \ldots \ldots \ldots \ldots \ldots \ldots \ldots$

Monitoring and Analyses $\ldots \ldots \ldots \ldots \ldots \ldots \ldots \ldots \ldots \ldots \ldots \ldots \ldots$

Radiation Monitoring Conclusions ....................... 37 


\section{TABLE OF CONTENTS (Cont.)}

Assessment of Radiation Dose-to-Man $\ldots \ldots \ldots \ldots \ldots \ldots \ldots \ldots \ldots \ldots \ldots \ldots \ldots$

Control of Chemical and Hazardous Wastes $\ldots \ldots \ldots \ldots \ldots \ldots \ldots \ldots \ldots . \ldots \ldots$

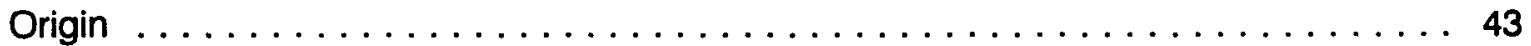

Control Programs $\ldots \ldots \ldots \ldots \ldots \ldots \ldots \ldots \ldots \ldots \ldots \ldots \ldots \ldots \ldots, 43$

Treatment and Disposal Programs $\ldots \ldots \ldots \ldots \ldots \ldots \ldots \ldots \ldots \ldots \ldots$

Control of Radioactive Waste Materials $\ldots \ldots \ldots \ldots \ldots \ldots \ldots \ldots \ldots \ldots \ldots$

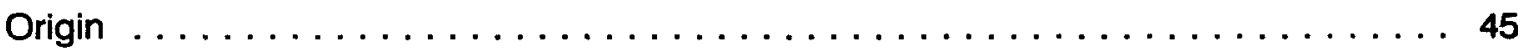

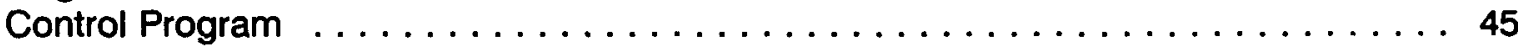

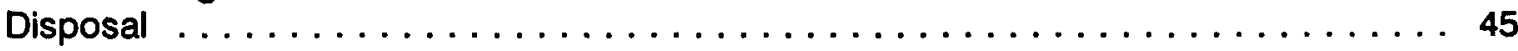

Environmental and Effluent Monitoring Quality Assurance $\ldots \ldots \ldots \ldots \ldots \ldots$

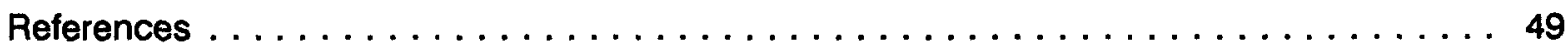

Appendix A Liquid Effluent Organic Analytes $\ldots \ldots \ldots \ldots \ldots \ldots \ldots \ldots \ldots \ldots$

Appendix B NRF Drinking Water System Volatile Organic Chemical (VOC) Analytes ... 53

Appendix C NRF Drinking Water System Synthetic Organic Chemical (SOC) Analytes . 55

Appendix D 1993 USEPA Cross Check Chemistry Results for NRF Chemistry Laboratory . . . . . . . . . . . . 57

Appendix E 1993 USDOE Cross Check Chemistry Results for NRF Chemistry Laboratory $\ldots \ldots \ldots \ldots \ldots \ldots \ldots \ldots \ldots \ldots$ 


\section{LUST OF TABLES}

Table

Number

Title

Page

Table $1 \quad$ Radiological Environmental Monitoring Program $\ldots \ldots \ldots \ldots \ldots$

Table 2 Nonradiological Environmental Monitoring Program $\ldots \ldots \ldots \ldots$

Table 3 Summary of Effluent Water Quality Analyses,

Calendar Year $(C Y) 1993 \ldots \ldots \ldots$. . . . . . . . . . . . . . 17

Table 4 Summary of Ground Water Analyses -

Inorganic and Other Selected Parameters, CY $1993 \ldots \ldots \ldots$

Table $5 \quad$ Summary of Drinking Water Radioactivity Results, CY $1993 \ldots \ldots \ldots$

Table 6 Summary of Ground Water Radioactivity Results, CY $1993 \ldots \ldots$

Table $7 \quad$ Summary of Soil, Sediment and Vegetation

Gamma Radioactivity Results, CY 1993 . . . . . . . . . . . . . . . 34

Table 8 Environmental lonizing Radiation Measurements for the

Naval Reactors Facility, CY 1993. . . . . . . . . . . . . . . . . . . 40

Table 9 Summary of Calculated Radiation Dose-to-Man from

NRF Operations, CY $1993 \ldots \ldots \ldots \ldots \ldots \ldots \ldots$

\section{LIST OF FIGURES}

Figure

Number

Title

Page

Figure $1 \quad$ Relation of NRF to the INEL $\ldots \ldots \ldots \ldots \ldots \ldots \ldots \ldots \ldots \ldots \ldots \ldots \ldots \ldots$

Figure $2 \quad$ NRF Area within the Security Fence $\ldots \ldots \ldots \ldots \ldots \ldots$

Figure $3 \quad$ Ground Water Monitoring Network $\ldots \ldots \ldots \ldots \ldots \ldots$

Figure 4 Soil, Sediment and/or Vegetation Monitoring Locations $\ldots \ldots \ldots \ldots$

Figure $5 \quad$ NRF Environmental Dosimeter Locations $\ldots \ldots \ldots \ldots \ldots \ldots \ldots$

Figure 6 DOE-RESL Environmental Dosimeter Locations for

Distant Communities . . . . . . . . . . . . . . . . . . . . . . . . . 39 
This page intentionally left blank. 


\section{ABSTRACT}

The results of the radiological and nonradiological environmental monitoring programs for 1993 at the Naval Reactors Facility (NRF) are presented in this report. The results obtained from the environmental monitoring programs verify that releases to the environment from operations at NRF were in accordance with state and federal regulations. Evaluation of the environmental data confirms that the operation of NRF continues to have no adverse effect on the quality of the environment or the health and safety of the general public. Furthermore, a conservative assessment of radiation exposure to the general public as a result of NRF operations demonstrated that the dose received by any member of the public was well below the most restrictive dose limits prescribed by the Environmental Protection Agency (EPA) and the Department of Energy (DOE). 
This page intentionally left blank. 


\section{SUMMARY}

The results of the radiological and nonradiological environmental monitoring programs for NRF are summarized below. Current operations at NRF are in compliance with applicable regulations governing use, emission, and disposal of solid, liquid, and gaseous materials. Current operations at NRF did not result in any significant release of radioactivity or hazardous materials to the environment.

- Liquid Releases (Other than to Sanitary Sewer): Approximately 170 million gallons of water were released to the environment via the Industrial Waste Ditch (IWD). No radioactivity attributable to operations at the NRF Site was detected in any of the environmental samples from these releases. Radioactivity concentrations were either below minimum detectable levels or were typical of natural background levels in water from the Snake River Aquifer.

Monitoring data for chemical constituents of liquid wastewater effluents continued to demonstrate compliance with U. S. Department of Energy and applicable state and federal regulations.

- Sanitary Sewer Discharges: All sanitary effluents were discharged to the NRF sewage treatment lagoon. No radioactivity attributable to operations at the NRF Site was detected in any of the environmental samples of sanitary effluent. All wastes discharged to the sanitary system were in compliance with applicable regulations.

- Ground Water Monitoring: Analysis of water from ground water wells collected onsite and offsite, did not detect any radioactivity in excess of natural background levels.

The results from the majority of the ground water analyses for a variety of chemicals were less than minimum detectable levels; however sodium, a nonhazardous salt constituent likely resulting from water softening processes, and background levels of nitrates were detected in the ground water. None of these constituents exceeded primary drinking water standards.

- Airborne Effluent: Airborne radioactivity in NRF effluents was controlled using high efficiency particulate air filters and, in some cases, charcoal filters to maintain particulate and gaseous radioactivity releases to as low as reasonably achievable. The results of NRF's airborne radiological effluent monitoring for 1993 have shown that the amount of radioactivity released was too small to result in any measurable change in the background radioactivity levels in the environment. The concentrations of the particulate and gaseous radioactivity released from the NRF Site during 1993 were well within the applicable standards for radioactivity in the environment.

The quantity of long-lived (greater than one day half-life) particulate radioactivity released in airborne effluents from NRF was 0.000067 curie. The quantity of long-lived gaseous radioactivity released was 0.98 curie of which carbon-14 and tritium were the principal contributors. The quantity of short-lived radioactivity released was 0.32 curie of which argon- 41 was the principal contributor.

Emissions of nonradiological air effluents were conservatively estimated and were well below applicable EPA and State of Idaho standards. 
- Environmental Radiological Monitoring: NRF operations in 1993 did not contribute to any measurable increase in radiation levels of man-made radioactivity in the surrounding environment. Although some low levels of radioactivity are present in the soil at some localized areas at NRF as a result of past operations, this radioactivity does not present a significant risk to onsite personnel, the general public or the environment. These areas are monitored on a routine basis to verify that radioactivity is not migrating and to ensure that the risk remains insignificant.

- Radiation Monitoring: Measurement of radiation along the NRF security fence was performed independently by NRF and the DOE Radiological and Environmental Sciences Laboratory. A comparison of the average reading along the NRF security fence and the average background reading measured by NRF at locations on the Idaho National Engineering Laboratory (INEL) 5 to 10 miles away from NRF indicates that NRF does not contribute to an increase in radiation levels.

- Radiation Dose-to-Man: Radiation exposure to the general public from NRF airborne releases was too low to measure and could only be estimated using conservative EPA approved calculational models. Direct exposure as a result of NRF operations was also too low to measure and was calculated. The resultant evaluation of all exposure pathways conservatively estimated a maximum annual hypothetical dose of 0.00062 millirem to an individual offsite. This dose is less than 0.006 percent of the conservative numerical guide established by the $U$. S. Department of Energy for continuous exposure to any member of the general public. This dose is negligible when compared to the approximately 350 millirem received by an individual from natural background radiation.

- Control of Chemical and Hazardous Wastes: Chemically hazardous materials were not manufactured nor disposed of at the NRF Site. However, chemically hazardous wastes were generated during site operations. These wastes were handled, controlled and stored by trained personnel in accordance with applicable federal and state regulations. Disposal was arranged with waste vendors operating under state and federal permits.

- Control of Radioactive Waste Materials: The volume of solid, low-level radioactive waste was minimized by limiting the materials that could become contaminated and by compacting wastes. Solid, low-level radioactive wastes were packaged in strong, tight containers meeting U. S. Department of Transportation requirements. Shipment of this waste to the DOE Radioactive Waste Management Complex (RWMC), located at the INEL, was controlled by written procedure to ensure compliance with state and federal regulations. 


\section{INTRODUCTION}

The Naval Reactors Facility (NRF) is operated for the U. S. Naval Nuclear Propulsion Program by Westinghouse Electric Corporation, Bettis-Idaho. It is located on the Idaho National Engineering Laboratory (INEL) 6.7 miles from the nearest INEL boundary (Figure 1). The developed portion of the site within the security fence covers approximately 84 of the 4400 acres under the cognizance of NRF. The INEL Site, including NRF, is not accessible by the general public. Two operating naval reactor prototypes, $A 1 W$ and $S 5 G$, and the Expended Core Facility (ECF) are located within the NRF security fence (Figure 2). A third naval reactor prototype, S1W, concluded operation in October 1989, and was deactivated in 1990. The two operating prototype plants are utilized to test advanced naval reactor components and materials. The prototype plants are also used as training platforms for United States Navy personnel who will serve aboard nuclear powered warships. Developmental nuclear fuel material samples, irradiated naval fuel and reactor plant components and materials are examined at ECF and the knowledge gained is used to improve current designs and to monitor the performance of existing reactors. ECF also prepares naval fuel for transport to the Idaho Chemical Processing Plant.

The purpose of this report is to summarize the NRF environmental monitoring program results for calendar year 1993. This report also evaluates current operations at NRF and documents compliance with applicable regulations governing use, emission, and disposal of solid, liquid, and gaseous materials.

\section{GEOLOGICAL AND DEMOGRAPHIC SITE DESCRIPTION}

The NRF Site is located on a parcel of land within the boundaries of the INEL. The INEL is comprised of 569,000 acres extending across the northeast portion of the Snake River Plain which covers parts of Butte, Jefferson, Bingham, Clark, and Bonneville counties in Idaho. The Snake River Plain is an L-shaped plateau approximately 200 miles long and 50 to 70 miles wide. Within its land area of 12,000 square miles, the plain descends from an elevation of 6000 feet in the east, near Ashton, to 2300 feet in the west, near Boise. The plain is naturally bordered on all sides by mountains, some exceeding 12,000 feet in elevation.

The NRF Site is underlain by a succession of interlocking flows of basaltic lava. These lava flows form layers of hard rock varying in thickness from 10 to 100 feet. The Snake River Aquifer lies approximately 360 feet below the land surface, and due to the sloping gradient of the subsurface basaltic formation, ground water flows generally to the south and west (Reference 1). Located in a semi-arid desert environment, the average annual temperature at NRF is 42 degrees Fahrenheit with extremes of -47 degrees Fahrenheit to 103 degrees Fahrenheit. Precipitation at NRF averages approximately 9 inches annually, and prevailing winds are out of the southwest.

The largest surrounding urban areas of the INEL include Pocatello to the southeast and Idaho Falls to the east. Both cities are approximately 45 to 50 air miles from NRF. Small farming communities are located on the western, northwestern, and southeastern boundaries of the INEL. The surrounding area, within 50 miles from the INEL borders, contains a population of approximately 150,000 . 


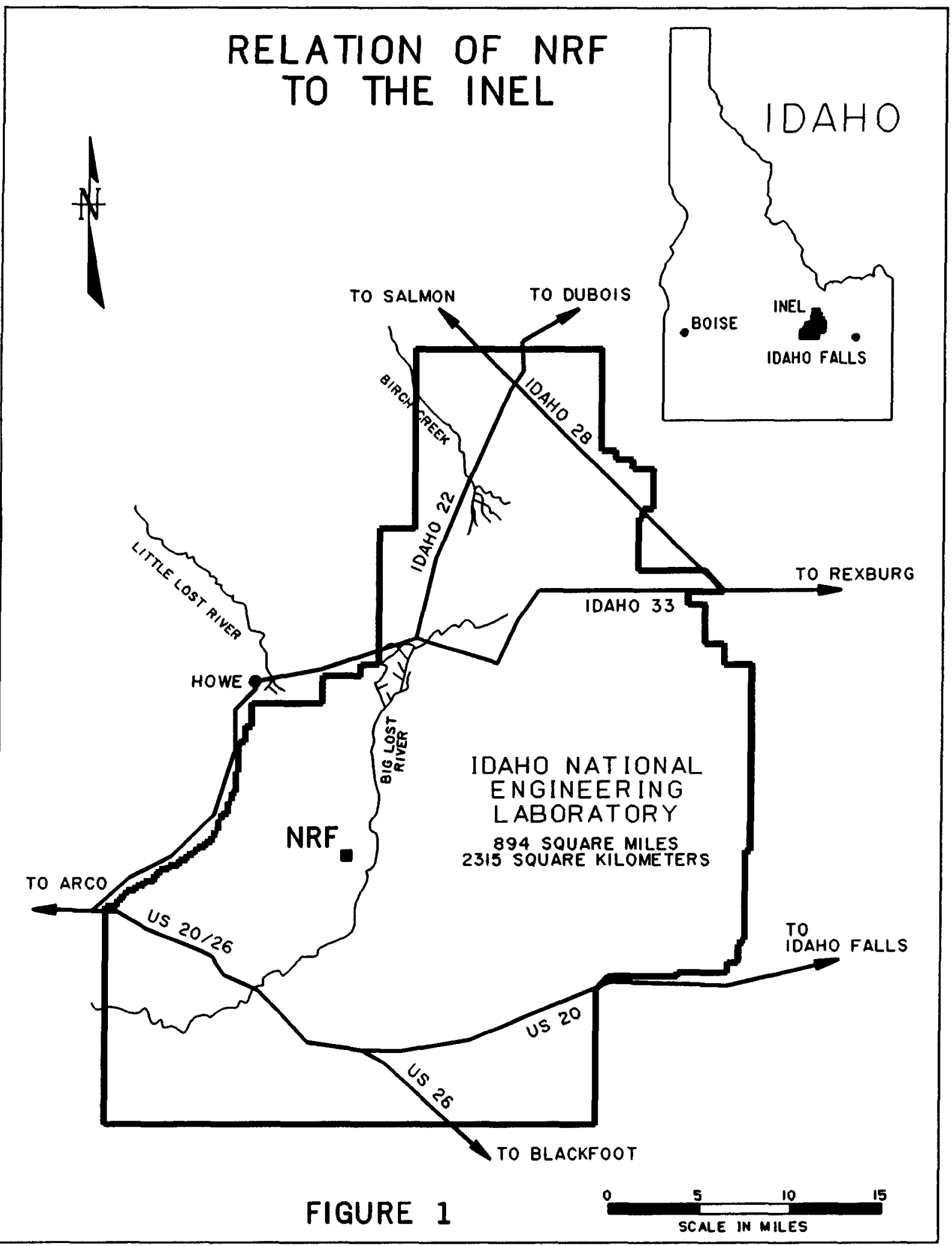




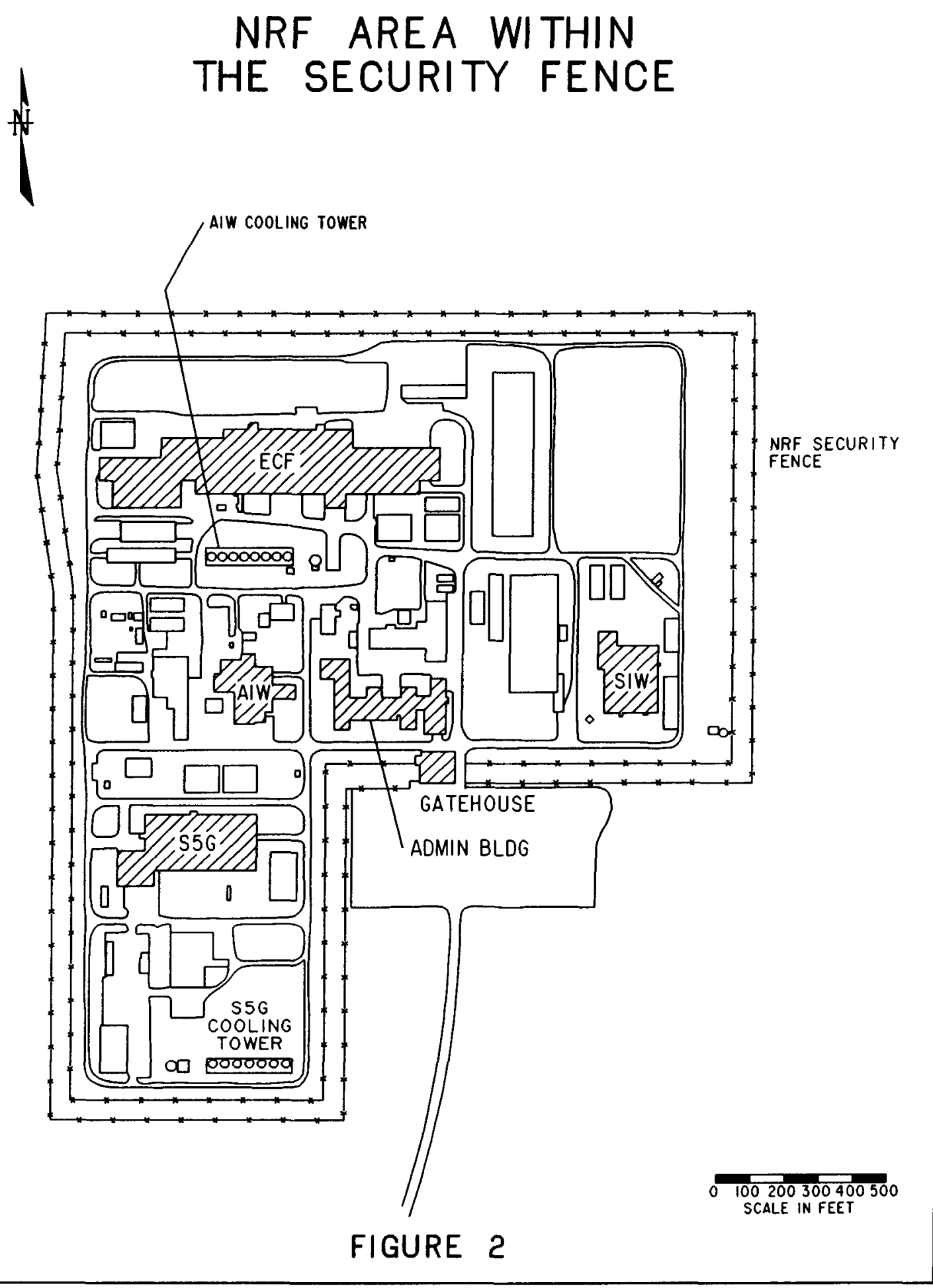


This page intentionally left blank. 


\section{ENVIRONMENTAL MONITORING}

\section{PROGRAM OVERVIEW}

The NRF environmental monitoring program, which includes radiological and nonradiological monitoring, is conducted in accordance with accepted monitoring procedures and management practices to ensure compliance with applicable state and federal standards. A complete synopsis of sampling and analyses performed in 1993 for the NRF environmental monitoring program can be found in Tables 1 and 2 . Data from this monitoring program confirm that operations at NRF have had no significant impact on human health or the environment.

Samples of liquid effluents are collected during discharge from the Industrial Waste Ditch outfall and to the Sanitary Sewage Lagoon. These samples are analyzed for chemical constituents and radioactivity to confirm that no hazardous wastes or radioactivity have been discharged to the environment.

The ground water monitoring program involves the collection of samples of ground water to ensure a high quality drinking water supply and to ascertain whether operations have had any measurable impact on the ground water.

Samples are collected from fourteen ground water wells at or near NRF. These samples are analyzed for chemical constituents and radioactivity. In addition, drinking water samples collected throughout the NRF distribution system are monitored for the presence of coliform bacteria in accordance with Reference 2.
Airborne effluents are monitored to ensure emissions meet state and federal standards. Emissions of combustion gases from steam generating boiler units are calculated using the sulfur content of the fuel oil. Particulate matter in the air is monitored at NRF by the Department of Energy Radiological and Environmental Sciences Laboratory (DOERESL). The exhaust air emitted from the radiological facilities is continuously monitored for radioactivity by NRF.

Continuous direct measurement of radiation levels at the NRF Site is accomplished by locating dosimeters along the security fence. This monitoring is conducted by NRF and independently by DOE-RESL. In addition, DOE-RESL measures radiation levels at offsite background locations.

NRF, because it is located on the INEL, is party to a Federal Facility Agreement and Consent Order (FFA/CO) for environmental remediation under the Comprehensive Environmental Response, Compensation and Liability Act (CERCLA). Surface water, perched water, ground water, surface soils, ditch sediments and subsurface soils were also sampled and analyzed as part of the Remedial Investigation and Feasibility Study (RI/FS) on the Industrial Waste Ditch. The results of this investigation were documented in the 1993 Draft RI/FS Report which concluded that no further remedial action is required. The State of Idaho and the EPA have concurred with this conclusion and have indicated they will issue a Record of Decision in 1994. This Record of Decision will also provide the decision documentation for other proposed remedial actions under the FFA/CO at NRF. 
TABLE 1

RADIOLOGICAL ENVIRONMENTAL MONITORING PROGRAM

(Page 1 of 3)

\begin{tabular}{|c|c|c|c|}
\hline Sample Location/Type & $\begin{array}{l}\text { Data/Sample } \\
\text { Collection } \\
\text { Method }\end{array}$ & $\begin{array}{l}\text { Analysis } \\
\text { Frequency }\end{array}$ & $\begin{array}{l}\text { Routine } \\
\text { Analysis }\end{array}$ \\
\hline \multicolumn{4}{|l|}{ INDUSTRIAL WASTE DITCH } \\
\hline Water (At Outfall) & Grab & Weekly & Gross gamma \\
\hline Water (At Outfall) & $\begin{array}{l}\text { Composite of } \\
\text { Weekly Grab } \\
\text { Samples }\end{array}$ & Monthly & Tritium \\
\hline Ditch Area & Survey & Annually & Gamma exposure \\
\hline Soil Samples & $\begin{array}{l}\text { Grab based on } \\
\text { survey }\end{array}$ & Annually & Quantitative isotopic gamma \\
\hline Sediment Samples & $\begin{array}{l}\text { Grab based on } \\
\text { survey }\end{array}$ & Annually & Quantitative isotopic gamma \\
\hline Vegetation Samples & $\begin{array}{l}\text { Grab based on } \\
\text { survey }\end{array}$ & Annually & Quantitative isotopic gamma \\
\hline \multicolumn{4}{|l|}{ COOLING TOWERS } \\
\hline A1W Water & Grab & Monthly & Gross gamma \\
\hline A1W Sediment & $\begin{array}{l}\text { Grab, marked } \\
\text { locations }\end{array}$ & Annually & Quantitative isotopic gamma \\
\hline S5G Water & Grab & Monthly & Gross gamma \\
\hline S5G Sediment & $\begin{array}{l}\text { Grab, marked } \\
\text { locations }\end{array}$ & Annually & Quantitative isotopic gamma \\
\hline
\end{tabular}

\section{SEWAGE LAGOONS}

Lagoon Area

Survey Annually

Gamma exposure

Lagoon Water

Grab

Annually

Gross gamma

Lagoon Sediment

Grab, marked Annually locations

Quantitative isotopic gamma

\section{AIR SAMPLING}

Fixed Filter Air Samplers

Continuous

Monthly

Gross alpha, beta

Tritium Samplers

Continuous

Monthly

Tritium

Charcoal Cartridges

Continuous

Weekly

lodine-131

ECF Water Pit Samples

Grab

Monthly

Carbon-14 and tritium 
TABLE 1

RADIOLOGICAL ENVIRONMENTAL MONITORING PROGRAM

(Page 2 of 3)

\begin{tabular}{|c|c|c|c|}
\hline Sample Location/Type & $\begin{array}{l}\text { Data/Sample } \\
\text { Collection } \\
\text { Method }\end{array}$ & $\begin{array}{l}\text { Analysis } \\
\text { Frequency }\end{array}$ & $\begin{array}{l}\text { Routine } \\
\text { Analysis }\end{array}$ \\
\hline \multicolumn{4}{|l|}{ DRINKING WATER } \\
\hline Onsite Wells & Grab & Monthly & Gross alpha, beta \\
\hline \multicolumn{4}{|l|}{ GROUND WATER } \\
\hline $\begin{array}{l}\text { Upgradient Wells } \\
\text { System Monitoring Wells } \\
\text { Onsite Wells } \\
\text { Downgradient Wells }\end{array}$ & Grab & Quarterty & Gross alpha, beta \\
\hline Onsite Wells & Grab & Monthly & Gross gamma \\
\hline
\end{tabular}

GENERAL SITE

RADIATION MONITORING

NRF Perimeter Fence

Survey

Annually

Gamma exposure

Background Dosimeters

Survey

Annually

Gamma exposure

Environmental

Continuous

Quarterly

Gamma exposure

(Perimeter, Background)

\section{AREAS OF RESIDUAL}

\section{RADIOACTIVITY}

Surface Areas

Survey

Annually

Gamma exposure

Soil Samples

Grab based on survey

Annually

Quantitative isotopic gamma

INACTIVE PIPELINES
Surface Areas
Soil Samples

Survey

Annually

Grab based on Annually

Gamma exposure 


\section{TABLE 1}

\section{RADIOLOGICAL ENVIRONMENTAL MONITORING PROGRAM}

(Page 3 of 3)

\begin{tabular}{|c|c|c|c|}
\hline Sample Location/Type & $\begin{array}{l}\text { Data/Sample } \\
\text { Collection } \\
\text { Method }\end{array}$ & $\begin{array}{l}\text { Analysis } \\
\text { Frequency }\end{array}$ & $\begin{array}{l}\text { Routine } \\
\text { Analysis }\end{array}$ \\
\hline \multicolumn{4}{|l|}{ SIW SEEPAGE BASIN } \\
\hline Surface Areas & Survey & Annually & Gamma exposure \\
\hline Soil Samples & $\begin{array}{l}\text { Grab, marked } \\
\text { locations }\end{array}$ & Annually & Quantitative isotopic gamma \\
\hline Vegetation Samples & $\begin{array}{l}\text { Grab, marked } \\
\text { locations }\end{array}$ & Annually & Quantitative isotopic gamma \\
\hline \multicolumn{4}{|l|}{ A1W SEEPAGE BASIN } \\
\hline Surface Areas & Survey & Annually & Gamma exposure \\
\hline Soil Samples & $\begin{array}{l}\text { Grab, marked } \\
\text { locations }\end{array}$ & Annually & Quantitative isotopic gamma \\
\hline Vegetation Samples & $\begin{array}{l}\text { Grab, marked } \\
\text { locations }\end{array}$ & Annually & Quantitative isotopic gamma \\
\hline \multicolumn{4}{|l|}{$\begin{array}{l}\text { DOWNWIND OF EXHAUST } \\
\text { STACKS }\end{array}$} \\
\hline Surface Areas & Survey & Annually & Gamma exposure \\
\hline Soil Samples & $\begin{array}{l}\text { Grab, marked } \\
\text { locations }\end{array}$ & Annually & Quantitative isotopic gamma \\
\hline Vegetation Samples & $\begin{array}{l}\text { Grab, marked } \\
\text { locations }\end{array}$ & Annually & Quantitative isotopic gamma \\
\hline
\end{tabular}




\title{
TABLE 2
}

\section{NONRADIOLOGICAL ENVIRONMENTAL MONITORING PROGRAM}

\author{
(Page 1 of 2)
}

\section{Data/Sample Collection Method}

\begin{abstract}
Outfall
\end{abstract}
0.2 Miles Downstream of Outfall

\section{Sample Location \\ INDUSTRIAL WASTE DITCH}

0.2 Miles Downstream of
Outfall

\section{SEWAGE LAGOONS}

Active Lagoon

(Northeast celi)
Grab

Grab

Grab

Annually

Grab

Annually

\section{Analysis \\ Frequency}

Weekly

Grab

Monthly
Monthly

\section{Routine \\ Analysis}

Aluminum, ammonia nitrogen

(dissolved), barium, bromide, chloride, chromium (total), fluoride, iron (total), lead, manganese, mercury, nickel, nitrogen measured as nitrate-nitrite, organic carbon (total), $\mathrm{pH}$, phosphorus, silver, sodium, specific conductance, sulfate, total dissolved solids, total suspended solids, zinc

Barium, chloride, chromium (total), lead, mercury, nitrogen measured as nitrate-nitrite, oil and grease, $\mathrm{pH}$, silver, sodium, sulfate, total dissolved solids, total suspended solids

Antimony, arsenic, barium, beryllium, cadmium, chromium (total), copper, cyanide (total), lead, mercury, nickel, selenium, silver, sulfide, thallium, vanadium, zinc

Semi-volatile organic compounds, volatile organic compounds, herbicides, organochlorine insecticides, benzene hexachlorides, aroclors, and dioxin screen (The specific analytes for these chemical types are listed in Appendix A)

Barium, biochemical oxygen demand (BOD), chloride, chromium (total), dissolved oxygen (DO), lead, mercury, nitrogen measured as nitrate-nitrite, oil and grease, $\mathrm{pH}$, silver, sodium, sulfate, total dissolved solids, total suspended solids 
TABLE 2

NONRADIOLOGICAL ENVIRONMENTAL MONITORING PROGRAM

(Page 2 of 2)

\begin{tabular}{|c|c|c|c|}
\hline Sample Location & $\begin{array}{l}\text { Data/Sample } \\
\text { Collection } \\
\text { Method }\end{array}$ & $\begin{array}{l}\text { Analysis } \\
\text { Frequency }\end{array}$ & $\begin{array}{l}\text { Routine } \\
\text { Analysis }\end{array}$ \\
\hline \multicolumn{4}{|l|}{ DRINKING WATER } \\
\hline \multirow{2}{*}{$\begin{array}{l}\text { Drinking Water } \\
\text { Distribution System }\end{array}$} & Grab & Monthly & Coliform bacteria (total) \\
\hline & Grab & $\begin{array}{l}\text { Regulatory } \\
\text { monitoring } \\
\text { performed this } \\
\text { year only }\end{array}$ & $\begin{array}{l}\text { Copper, lead, nitrogen measured as } \\
\text { nitrate, nitrogen measured as nitrite, } \\
\text { regulated and unregulated volatile } \\
\text { organic chemicals (The specific } \\
\text { analytes for these chemical groups ar } \\
\text { listed in Appendix B), regulated and } \\
\text { unregulated synthetic organic } \\
\text { chemicals (The specific analytes for } \\
\text { these chemical groups are listed in } \\
\text { Appendix C) }\end{array}$ \\
\hline \multicolumn{4}{|l|}{ GROUND WATER } \\
\hline $\begin{array}{l}\text { Upgradient Wells, } \\
\text { Onsite Wells, } \\
\text { System Monitoring } \\
\text { Wells, } \\
\text { Downgradient Wells }\end{array}$ & Grab & Quarterly & $\begin{array}{l}\text { Ammonia nitrogen (dissolved), } \\
\text { bromide, chloride, chromium (total), } \\
\text { fluoride, iron (total), lead, mercury, } \\
\text { nickel, nitrogen measured as nitrate- } \\
\text { nitrite, nitrogen measured as nitrite, } \\
\text { organic carbon (total), phosphorus } \\
\text { measured as orthophosphate, } \mathrm{pH}, \\
\text { silver, sodium, specific conductance, } \\
\text { sulfate, temperature }\end{array}$ \\
\hline
\end{tabular}




\section{LIQUID EFFLUENT MONITORING}

The purpose of the liquid effluent monitoring program is to confirm that no chemically hazardous or radioactive wastes have been discharged to the environment.

\section{Sources and Treatment}

- Nonradiological: Nonradioactive water disposal at NRF is segregated into two separate systems. Sanitary wastewater from the NRF facility is discharged to a sewage treatment lagoon. Water from NRF operations and stormwater runoff is discharged to the Industrial Waste Ditch (IWD).

Industrial Waste Ditch: The Industrial Waste Ditch at NRF consists of two discrete drainage systems. The interior IWD is comprised of a network of buried pipes, culverts and open channels within the NRF security fence. This network empties into a drainage system with an outfall at the northwest corner of the facility. The exterior IWD begins at this outfall and progresses 3.2 miles northeast into the desert from NRF along a former creek bed. Water discharged through the IWD system is dissipated through a combination of percolation, evaporation and evapotranspiration from plant life along the course of the exterior IWD. Normally, no surface water is visible beyond 1.6 miles from the outfall.

In 1993, approximately 170 million gallons of water were released to the IWD. Sources of water to the IWD include stormwater and snow-melt runoff; cooling tower, spray pond, secondary steam generator, site boiler facility, and site water softening facility discharges; and discharges resulting from the neutralization of ion exchange resin regenerating solutions produced by a facility that demineralizes water for various site operations.
Sewage Lagoon: Sanitary wastewater at NRF is conveyed to the northeast cell of a dual cell evaporative sewage lagoon. Approximately 12 million gallons of sanitary sewage were discharged to the sewage lagoon in 1993. The sewage lagoon is a facultative lagoon which combines aerobic and anaerobic digestion to break down solids. The remaining liquid is dissipated by a combination of percolation through soils and evaporation.

- Radiological: During 1993, as in previous years, a water reuse system was used whereby liquids containing radioactivity were collected, processed and reused rather than intentionally discharged to the environment.

\section{Monitoring and Analyses}

Liquid effluents discharged to the IWD and the sewage lagoon were analyzed for chemical constituents and radioactivity. The results of these analyses for the IWD are reported monthly in the INEL nonradiological waste management information system.

- Nonradiological: Grab samples of the effluents discharged to the IWD were collected weekly at the outfall of the interior drainage system and monthly downstream of the outfall at the 0.2 mile point of the exterior IWD. The downstream samples were collected at a lesser frequency since the highest concentrations were expected from the outfall samples. The outfall and 0.2 mile sample data were combined to calculate a grand mean for liquid effluent discharges. A summary of the liquid effluent monitoring results from the IWD as well as from the sewage lagoon is presented in Table 3. The results of this monitoring showed no appreciable concentrations of heavy metals and a near neutral $\mathrm{pH}$ in the liquid effluent. Inadvertent releases of small 
amounts of lubricating oil to the IWD occurred during the year. These releases were isolated at the IWD outfall and subsequently recovered using oil absorbent material. An upgrade of a prototype plant oil/water separation tank (i.e., the addition of a continuous oil content monitor to the outlet, and modification to allow automatic recirculation of the tank's contents if high oil content is detected) is intended to prevent similar oil releases in the future.

Varying levels of nonhazardous salts (containing ions of sodium, chloride, and sulfate) used to soften site water or resulting from the regeneration of nonradiological ion exchange systems were detectable in the liquid effluents from NRF. In addition, zinc and phosphorus were present at low levels originating from plant operations. Detectable levels of fluoride were also noted in NRF liquid effluent. These levels were attributed to the fluoride naturally occurring in ground water. None of these constituents were harmful to the environment at the levels discharged from NRF.

NRF effluent water was also monitored for the presence of hazardous organic constituents including herbicides and insecticides. No hazardous organic constituents were found in the liquid effluent. Specific chemical components of the hazardous organic analyses are summarized in Appendix $A$.

Grab samples of the effluent discharged to the sewage lagoon were collected from the northeast cell of the lagoon. The samples collected were analyzed for biochemical oxygen demand, dissolved oxygen, $\mathrm{pH}$ and other constituents presented in Table 3 . The analytical results of sewage effluent samples were typical of the ranges expected in a nonaerated evaporative sewage treatment lagoon.

- Radiological: At NRF, water containing radioactivity was collected, processed to re- move the radioactivity, and reused rather than intentionally discharged to the environment. This process system includes collection tanks, particulate filters, activated carbon columns and/or mixed bed ion exchange columns to remove radioactivity and inorganic material. The water processing practices ensured that over 99.9 percent of the gamma radioactivity contained in liquids associated with NRF operations was removed. The remaining 0.1 percent is retained in the water that is reused.

Water samples collected from the IWD, sewage lagoon and cooling towers were analyzed for gross gamma and tritium radioactivity. Gamma spectrometry was performed on these samples to identify gamma emitting radionuclides. Liquid scintillation was used to analyze for tritium. The analytical results confirmed that no radioactivity above natural background levels was present in liquid effluent streams discharged from NRF.

\section{Liquid Effluent Monitoring Conclusions}

- Nonradiological: The liquid effluent monitoring confirms that no chemically hazardous wastes were discharged from the NRF Site in 1993 and that all liquid effluents were controlled in accordance with applicable federal and state laws. The levels of nonhazardous salts of sodium, chloride, fluoride, and sulfate, and concentrations of nitrate-nitrite nitrogen, zinc, and phosphorus, that NRF discharged via the IWD and the sewage lagoon were below all applicable limits and not harmful to the environment.

- Radiological: No radioactive liquid effluents were discharged from NRF. The procedures and equipment used to process radioactive liquids have been effective in eliminating intentional discharges to the environment. 
TABLE 3

SUMMARY OF EFFLUENT WATER QUALITY ANALYSES, CALENDAR YEAR (CY) 1993 (Page 1 of 2)

\begin{tabular}{|c|c|c|c|c|c|c|c|c|}
\hline \multirow[b]{2}{*}{ PARAMETER } & \multirow[b]{2}{*}{ UNITS } & \multirow{2}{*}{$\begin{array}{l}\text { STANDARD or } \\
\text { GUIDELINE }\end{array}$} & \multicolumn{3}{|c|}{ INDUSTRIAL WASTE DITCH } & \multicolumn{3}{|c|}{ SEWAGE LAGOON } \\
\hline & & & MIN & $\operatorname{MAX}$ & MEAN $\pm s^{(2)}$ & MIN & MAX & $M E A N \pm s^{(2)}$ \\
\hline Aluminum & $\mathrm{mg} / \mathrm{l}$ & (1) & $<0045$ & 061 & $<02$ & -- & - & - \\
\hline $\begin{array}{l}\text { Ammonia } \\
\text { Nitrogen } \\
\text { (dissolved) }\end{array}$ & $\mathrm{mg} / \mathrm{l}$ & (1) & $<002$ & 0671 & $<01$ & --- & --- & $\ldots$ \\
\hline Antimony & $\mathrm{mg} / \mathrm{l}$ & (1) & (3) & (3) & $<030$ & (3) & (3) & $<030$ \\
\hline Arsenic & $\mathrm{mg} / \mathrm{l}$ & $50^{(4)}$ & (3) & (3) & $<00050$ & (3) & (3) & $<00050$ \\
\hline Barium & $\mathrm{mg} / \mathrm{l}$ & $100^{(4)}$ & $<003$ & 46 & $<02$ & 0012 & 0038 & $0025 \pm 0009$ \\
\hline Beryllium & $\mathrm{mg} / \mathrm{l}$ & (1) & (3) & (3) & $<00050$ & (3) & (3) & $<00050$ \\
\hline $\begin{array}{l}\text { Biochemical } \\
\text { Oxygen } \\
\text { Demand }\end{array}$ & $\mathrm{mg} / \mathrm{l}$ & (1) & -- & $\cdots$ & -- & 18 & 67 & $28 \pm 14$ \\
\hline Bromide & $\mathrm{mg} / \mathrm{l}$ & (1) & $<01$ & $<01$ & $<<01$ & -- & $\cdots$ & -- \\
\hline Cadmium & $\mathrm{mg} / \mathrm{l}$ & $10^{(4)}$ & (3) & (3) & $<0010$ & (3) & (3) & $<0010$ \\
\hline Chloride & $\mathrm{mg} / \mathrm{l}$ & (1) & 584 & 800 & $151 \pm 109$ & 88 & 110 & $100 \pm 9$ \\
\hline $\begin{array}{l}\text { Chromium } \\
\text { (total) }\end{array}$ & $\mathrm{mg} / \mathrm{l}$ & $50^{(4)}$ & 0011 & 007 & $<002$ & $<002$ & $<002$ & $<<002$ \\
\hline Copper & $\mathrm{mg} / \mathrm{l}$ & (1) & (3) & (3) & $<0011$ & (3) & (3) & 0011 \\
\hline Cyanide (total) & $\mathrm{mg} / \mathrm{l}$ & (1) & (3) & (3) & $<0005$ & (3) & (3) & $<0005$ \\
\hline Fluoride & $\mathrm{mg} / \mathrm{l}$ & (1) & 0093 & 0471 & $0263 \pm 0082$ & - & - & - \\
\hline Iron (total) & $\mathrm{mg} / \mathrm{l}$ & (1) & $<0007$ & 102 & $<027$ & - & -- & $\cdots$ \\
\hline Lead & $\mathrm{mg} / \mathrm{l}$ & $50^{(4)}$ & $<0045$ & $<01$ & $<<01$ & $<010$ & $<010$ & $<<010$ \\
\hline Manganese & $\mathrm{mg} / \mathrm{l}$ & (1) & $<0002$ & 007 & $<001$ & $\cdots$ & - & - \\
\hline Mercury & $\mathrm{mg} / \mathrm{l}$ & $02^{(4)}$ & $<00002$ & $<0001$ & $<0001$ & $<00002$ & 00003 & $<00002$ \\
\hline Nickel & $\mathrm{mg} / \mathrm{l}$ & (1) & $<0015$ & 013 & $<003$ & (3) & (3) & $<0040$ \\
\hline $\begin{array}{l}\text { Nitrate-Nitrite } \\
\text { Nitrogen }\end{array}$ & $\mathrm{mg} / \mathrm{I}$ & (1) & 0735 & 733 & $38 \pm 14$ & $<01$ & $<01$ & $<<01$ \\
\hline $\begin{array}{l}\text { Oll and } \\
\text { Grease }\end{array}$ & $\mathrm{mg} / \mathrm{l}$ & (1) & $<5$ & $<5$ & $<<5$ & $<5$ & 44 & $<12$ \\
\hline $\begin{array}{l}\text { Organic } \\
\text { Carbon (total) }\end{array}$ & $\mathrm{mg} / \mathrm{l}$ & (1) & $<1$ & 332 & $<1$ & -- & - & -- \\
\hline $\begin{array}{l}\text { Oxygen } \\
\text { (dissolved) }\end{array}$ & $\mathrm{mg} / \mathrm{l}$ & (1) & -- & -- & -- & 06 & 214 & $92 \pm 68$ \\
\hline $\mathrm{pH}$ & $\mathrm{pH}$ & 20 to $125^{(4)}$ & 67 & 84 & $76 \pm 03$ & 79 & 113 & $97 \pm 08$ \\
\hline
\end{tabular}


TABLE 3

SUMMARY OF EFFLUENT WATER QUALITY ANALYSES, CY 1993

(Page 2 of 2)

\begin{tabular}{|c|c|c|c|c|c|c|c|c|}
\hline \multirow[b]{2}{*}{ PARAMETER } & \multirow[b]{2}{*}{ UNITS } & \multirow[b]{2}{*}{$\begin{array}{l}\text { STANDARD or } \\
\text { GUIDELINE }\end{array}$} & \multicolumn{3}{|c|}{ INDUSTRIAL WASTE DITCH } & \multicolumn{3}{|c|}{ SEWAGE LAGOON } \\
\hline & & & $M I N$ & MAX & MEAN $\pm s^{(2)}$ & MIN & $\operatorname{MAX}$ & MEAN $\pm s^{(2)}$ \\
\hline Phosphorus & $\mathrm{mg} / 1$ & (1) & 0.285 & 2.98 & $1.36 \pm 0.52$ & - & $\cdots$ & - \\
\hline Selenium & $\mathrm{mg} / \mathrm{l}$ & $1.0^{(4)}$ & (3) & (3) & $<0.0050$ & (3) & (3) & $<0.0050$ \\
\hline Silver & $\mathrm{mg} / \mathrm{l}$ & $5.0^{(4)}$ & $<0.007$ & $<0.01$ & $<0.01$ & $<0.010$ & $<0.010$ & $<<0.010$ \\
\hline Sodium & $\mathrm{mg} / \mathrm{l}$ & (1) & 30.7 & 700 & $104 \pm 108$ & 157 & 235 & $199 \pm 28$ \\
\hline $\begin{array}{l}\text { Specific } \\
\text { Conductance }\end{array}$ & $\begin{array}{c}\mu \mathrm{mho} \\
/ \mathrm{cm}\end{array}$ & (1) & 123 & 3400 & $1134 \pm 492$ & $\cdots$ & - & - \\
\hline Sulfate & $\mathrm{mg} / \mathrm{l}$ & (1) & 56.3 & 1250 & $248 \pm 156$ & 64 & 140 & $89 \pm 23$ \\
\hline Sulfide & $\mathrm{mg} / \mathrm{l}$ & (1) & (3) & (3) & 1 & (3) & (3) & $<1$ \\
\hline Thallium & $\mathrm{mg} / \mathrm{l}$ & (1) & (3) & (3) & $<0.50$ & (3) & (3) & $<0.50$ \\
\hline $\begin{array}{l}\text { Total Dissolved } \\
\text { Solids }\end{array}$ & $\mathrm{mg} / \mathrm{l}$ & (1) & 428 & 2143 & $793 \pm 296$ & 530 & 790 & $668 \pm 88$ \\
\hline $\begin{array}{l}\text { Total Suspended } \\
\text { Solids }\end{array}$ & $\mathrm{mg} / \mathrm{l}$ & (1) & $<2$ & 29 & $<6$ & 21 & 110 & $69 \pm 35$ \\
\hline Vanadium & $\mathrm{mg} / \mathrm{l}$ & (1) & (3) & (3) & $<0.050$ & (3) & (3) & $<0.050$ \\
\hline Zinc & $\mathrm{mg} / \mathrm{l}$ & (1) & 0.029 & 0.458 & $0.136 \pm 0.088$ & (3) & (3) & 0.11 \\
\hline
\end{tabular}

(1) This parameter is monitored to help characterize any possible influence of NRF liquid effluent on a perched water zone located north of NRF.

(2) Mean values recorded \pm 1 standard deviation (s). Mean values preceded by < contained at least one "less than minimum detection level" (MDL) value in the data set for that parameter. Mean values preceded by $<<$ contained all "less than minimum detection level" values in the data set for that parameter and were the average of the MDLs.

(3) Sampled and analyzed once, annually; therefore no minimum, maximum, or mean standard deviation available.

(4) Code of Federal Regulations, Title 40, Part 261, Subpart C. 


\section{GROUND WATER MONITORING}

NRF conducts a comprehensive ground water monitoring program to ensure a high quality drinking water supply and to verify that NRF operations have not adversely affected the quality of the ground water.

\section{Sources and Treatment}

The Snake River Aquifer is approximately 360 feet below the ground surface at NRF. Previous studies at the INEL have determined that the ground water moves in a horizontal direction at an average rate of 5 to 20 feet per day from the northeast to the southwest (Reference 1).

Figure 3 plots the location of all deep wells used for ground water monitoring at NRF. Four of these wells are within the NRF security fence (NRF 1, 2, 3, and 4) and were monitored concurrently by NRF and the United States Geological Survey (USGS). These "onsite" wells provided all water required for production and domestic use. The other ten wells are located within a 3.6 mile radius of the NRF Site and were sampled by the USGS. Two of these wells, located just north of NRF and termed "system" wells (NRF 6 and 7), were drilled in 1991 to assist in monitoring the potential migration of liquid effluent from the IWD and the sewage lagoon. Three monitoring wells (USGS $12,15,17$ ) are located farther north and east of NRF than the system wells. These wells were termed the "upgradient" monitoring wells because of their relation to the hypothesized flow of the aquifer and NRF. The last five wells were classified as "downgradient" and are located south and west of NRF (USGS 97, 98, 99, 102, and INEL 1P). Each group of wells (upgradient, system, onsite, and downgradient) was used to monitor and study trends in ground water composition beneath NRF and the surrounding area.
Operations at NRF require the use of demineralized water. To achieve this, water is withdrawn from the onsite wells and processed through a demineralizer. Periodically, the ion exchange resins in the demineralizers are restored to full ion exchange capacity through regeneration with sulfuric acid and sodium hydroxide solutions. These solutions are then neutralized in the NRF elementary neutralization facility, and the $\mathrm{pH}$ is monitored, prior to their discharge as nonhazardous liquids. Neutralization facilities are operated in accordance with federal and state regulatory requirements.

Water withdrawn from the onsite wells is naturally high in calcium and magnesium (hard water). Therefore, water for domestic use and some water for use in the prototype plants is processed through a water softening system. This system utilizes common salt as the water softening agent. The use of softened water significantly reduces hard water deposits or scale buildup which extends equipment life, reduces maintenance costs, and minimizes the need to use other chemical treatments to contend with the consequences of using hard water.

\section{Monitoring and Analyses}

NRF has a ground water monitoring program which includes the collection and analysis of drinking water samples in compliance with requirements established by the State of Idaho and the Safe Drinking Water Act. Also included in this program are the analyses of samples from monitoring wells surrounding NRF. In 1993, analyses for the program were conducted by the USGS, DOE-RESL, and other contract laboratories. The samples collected from ground water wells throughout 1993 were analyzed for chemical constituents and 
radioactivity. The NRF drinking water distribution system was also analyzed for the presence of coliform bacteria.

- Nonradiological: Drinking water samples were collected monthly and analyzed for the presence of coliform bacteria. The frequency of this monitoring met the requirements of applicable state and federal regulations. Sampling locations were varied and randomly selected at points throughout the distribution system. These samples were analyzed by the EG\&G Industrial Hygiene Laboratory (State of Idaho certified) which confirmed the absence of coliform bacteria in the water supply.

Drinking water samples were also collected from source water prior to entering the distribution system and monitored for Volatile Organic Compounds (VOCs), Synthetic Organic Compounds (SOCs), nitrates and nitrites. No VOCs or SOCs, listed in Appendix B and $C$ respectively, were detected above the minimum detection levels established for the analyses of these compounds. Concentrations of nitrates and nitrites were well below regulatory limits.

Lead and copper monitoring of the NRF drinking water system was initiated in 1993 in accordance with applicable state and federal regulations. Initial monitoring identified three sampling locations which exceeded the action level for lead (15 parts per billion). Exceeding the action level for lead prompted additional monitoring of source water and treated drinking water for water quality parameters such as $\mathrm{pH}$, alkalinity, calcium, conductivity and water temperature. Follow up sampling, additional system monitoring, and an evaluation of treatment alternatives are underway to ensure lead concentrations are minimized below the action level. No action levels for copper were exceeded.
Ground water monitoring was conducted through the collection and analysis of samples from upgradient, system, onsite and downgradient wells. These samples were analyzed for inorganic chemical constituents and other selected parameters and are summarized in Table 4. Samples from NRF wells 6 and 7 were analyzed to monitor the potential migration from the IWD and the sewage lagoon. Data collected from these wells are reported separately in Table 4, to eliminate biasing the data from onsite production wells. This also ensures that drinking water monitoring data is directly comparable to the data reported for NRF wells $1,2,3$, and 4 under the ground water monitoring program.

The average ionic concentration of sodium measured at NRF wells 6 and 7 was higher than upgradient, onsite, or downgradient well groupings. This may be attributed to the discharge of salts from the site water softener and demineralization system (see Liquid Effluent Monitoring section). These wells were designed to monitor the influence of NRF liquid effluent on a perched water zone located north of NRF. The other three groups of wells showed no difference in average sodium concentrations. The concentration of this nonhazardous salt constituent was below recommended drinking water limits, and had no detrimental effect on the quality of the ground water.

NRF does not discharge any significant sources of nitrates, however, the average onsite and downgradient well concentrations of nitrate-nitrite nitrogen were slightly higher than the average upgradient well concentrations of the same parameter due to varying background concentrations. All measured nitrate concentrations were well below regulatory drinking water limits. 
- Radiological: Samples from the four production wells that may furnish drinking water to NRF were collected and analyzed by the DOE-RESL laboratory (State of Idaho certified) for radiological drinking water analyses. Analytical results reported for these samples were consistent with the standards identified in the Idaho Regulations for Public Drinking Water Systems. A summary of analyses results are provided in Table 5. All values for gross alpha, gross beta and tritium were below the limits established by Reference 2 for drinking water. Tritium values from NRF wells 1, 2, 3, and 4 are generally comparable to natural background concentrations measured in ground water on the INEL, and showed no increases over the tritium levels reported in 1992. Gross alpha and gross beta radioactivity levels are consistent with naturally occurring radionuclide levels.

Ground water samples from all fourteen wells were collected quarterly on a schedule consistent with the requirements outlined in NRF's Ground Water Monitoring Plan. These samples were also analyzed for dissolved gross alpha and gross beta radioactivity. The results of these analyses are shown in Table 6 . All values were less than drinking water standards for gross alpha and gross beta radioactivity. For all monitored wells, the detected radioactivity appears to be the result of naturally occurring radioactivity found within the Snake River Aquifer.

All radioactivity levels measured were below the limits from the concentration guides in Reference 2.

\section{Ground Water Monitoring Conclusions}

- Nonradiological: Monitoring of the NRF drinking water system for bacterial contaminants demonstrated compliance with public drinking water regulations and verified the system to be free of potentially harmful coliform bacteria. Drinking water monitoring also verified that no analyzed VOCs, SOCs, nitrates or nitrites were present in the NRF drinking water system above minimum detectable levels.

Most ground water monitoring parameter variations that existed between well groups were not statistically significant. NRF wells 6 and 7 , used to monitor the migration from the IWD and sewage lagoon, showed elevated average sodium concentrations when compared to the three other well test groups. The concentration of this nonhazardous water softening and demineralization process ion had no detrimental effect on the quality of the ground water. Also noted were slightly elevated nitrate-nitrite nitrogen concentrations in downgradient well groups when compared to upgradient well concentrations. The nitrate-nitrite nitrogen levels were well below primary drinking water standards as per Reference 2.

- Radiological: The radioactivity levels in the ground water were significantly below the concentration limits presented in Reference 2. Therefore, operations at NRF had no radiological effect on ground water. 


\section{GROUND WATER MONITORING \\ NE TWORK \\ - usgs well 15}

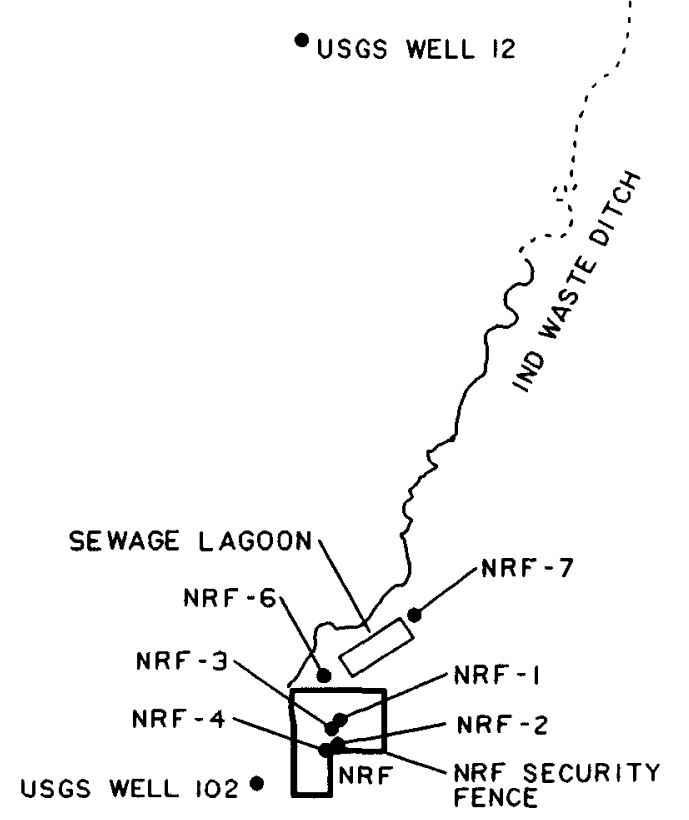

$\sqrt{1}$

USGS WELL 97

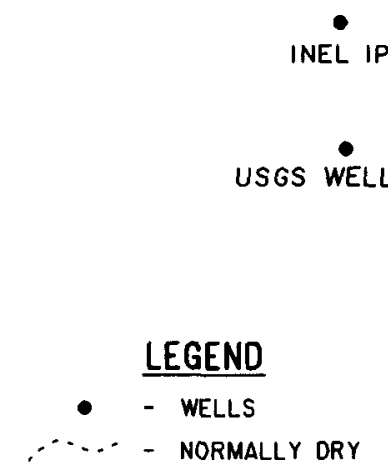

IP

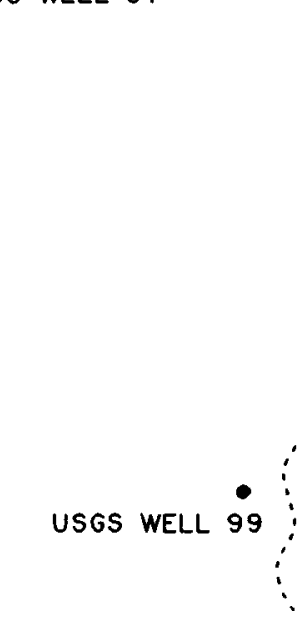

FIGURE 3

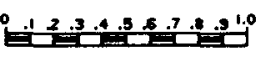

SCALE IN MILES 
TABLE 4

SUMMARY OF GROUND WATER ANALYSES - INORGANIC AND OTHER SELECTED PARAMETERS, CY 1993

(Page 1 of 2)

\begin{tabular}{|c|c|c|c|c|c|c|c|c|c|c|}
\hline \multirow{2}{*}{ PARAMETER } & \multirow{2}{*}{ UNITS } & \multirow{2}{*}{$\begin{array}{l}\text { CONCENTRATION } \\
\text { GUIDELINE }^{(1)}\end{array}$} & \multicolumn{2}{|c|}{$\begin{array}{c}\text { UPGRADIENT } \\
\text { (USGS WELLS 12, } 15 \& \text { 17) }\end{array}$} & \multicolumn{2}{|c|}{$\begin{array}{c}\text { SYSTEM } \\
\text { (NRF WELLS } 6 \& n\end{array}$} & \multicolumn{2}{|c|}{$\begin{array}{c}\text { ONSITE } \\
\text { (NRF WELS 1, 2, 3, \& 4) }\end{array}$} & \multicolumn{2}{|c|}{$\begin{array}{c}\text { DOWNGRADIENT } \\
\text { (USaS 97, 98, 99, } 102 \& \text { INEL 1P) }\end{array}$} \\
\hline & & & RANGE & MEAN $\pm s^{(2)}$ & RANGE & MEAN $\pm s^{(2)}$ & RANGE & MEAN $\pm s^{(2)}$ & RANGE & MEAN $\pm 8^{(2)}$ \\
\hline $\begin{array}{l}\text { AMMONIA } \\
\text { NITROGEN } \\
\text { (DISSOLVED) }\end{array}$ & $\mathrm{mg} / \mathrm{l}$ & (3) & $\begin{array}{l}<0.01 \\
\text { to } \\
0.04\end{array}$ & $<0.02$ & $\begin{array}{c}<0.01 \\
\text { to } \\
0.03\end{array}$ & $<0.02$ & $\begin{array}{c}<0.01 \\
\text { to } \\
0.03\end{array}$ & $<0.02$ & $\begin{array}{c}<0.01 \\
\text { to } \\
0.04\end{array}$ & $<0.02$ \\
\hline BROMIDE & $\mathrm{mg} / \mathrm{l}$ & (3) & $\begin{array}{c}0.01 \\
\text { to } \\
0.10\end{array}$ & $0.05 \pm 0.03$ & $\begin{array}{c}0.01 \\
\text { to } \\
0.10\end{array}$ & $0.05 \pm 0.04$ & $\begin{array}{l}0.07 \\
\text { to } \\
0.09\end{array}$ & $0.08 \pm 0.01$ & $\begin{array}{l}0.04 \\
\text { to } \\
0.29\end{array}$ & $0.11 \pm 0.09$ \\
\hline CHLORIDE & $\mathrm{mg} / \mathrm{l}$ & 250 & $\begin{array}{l}5.6 \\
\text { to } \\
38\end{array}$ & $18 \pm 14$ & $\begin{array}{l}4.8 \\
\text { to } \\
230\end{array}$ & $70 \pm 103$ & $\begin{array}{l}33 \\
\text { to } \\
49\end{array}$ & $42 \pm 5$ & $\begin{array}{c}14 \\
\text { to } \\
200\end{array}$ & $50 \pm 47$ \\
\hline $\begin{array}{l}\text { CHROMIUM } \\
\text { (TOTAL) }\end{array}$ & $\mathrm{mg} / \mathrm{l}$ & 0.1 & $\begin{array}{l}<0.001 \\
\text { to } \\
0.007\end{array}$ & $<0.004$ & $\begin{array}{l}0.010 \\
\text { to } \\
0.042\end{array}$ & $0.019 \pm 0.013$ & $\begin{array}{l}0.005 \\
\text { to } \\
0.021\end{array}$ & $0.009 \pm 0.004$ & $\begin{array}{c}0.003 \\
\text { to } \\
0.010\end{array}$ & $0.006 \pm 0.002$ \\
\hline FLUORIDE & $\mathrm{mg} / \mathrm{l}$ & 2.0 & $\begin{array}{l}<0.1 \\
\text { to } \\
0.2\end{array}$ & $<0.2$ & $\begin{array}{l}0.2 \\
\text { to } \\
0.3\end{array}$ & $0.2 \pm 0.0$ & 0.2 & $0.2 \pm 0.0$ & $\begin{array}{l}0.1 \\
\text { to } \\
0.2\end{array}$ & $0.2 \pm 0.0$ \\
\hline IRON (TOTAL) & $\mathrm{mg} / \mathrm{l}$ & 0.3 & $\begin{array}{c}<0.01 \\
\text { to } \\
0.14\end{array}$ & $<0.06$ & $\begin{array}{l}0.18 \\
\text { to } \\
1.10\end{array}$ & $0.46 \pm 0.31$ & $\begin{array}{l}<0.01 \\
\text { to } \\
3.20\end{array}$ & $<0.32$ & $\begin{array}{l}0.02 \\
\text { to } \\
2.00\end{array}$ & $0.35 \pm 0.51$ \\
\hline LEAD & $\mathrm{mg} / \mathrm{l}$ & 0.015 & $<0.001$ & $<<0.001$ & $<0.001$ & $<<0.001$ & $\begin{array}{c}<0.001 \\
\text { to } \\
0.003\end{array}$ & $<0.001$ & $\begin{array}{l}<0.001 \\
\text { to } \\
0.005\end{array}$ & $<0.002$ \\
\hline MERCURY & $\mathrm{mg} / \mathrm{l}$ & 0.002 & $<0.0001$ & $<<0.0001$ & $<0.0001$ & $<<0.0001$ & $<0.0001$ & $<<0.0001$ & $<0.0001$ & $<<0.0001$ \\
\hline NICKEL & $\mathrm{mg} / \mathrm{l}$ & 0.1 & $\begin{array}{l}<0.001 \\
\text { to } \\
0.002\end{array}$ & $<0.001$ & $\begin{array}{l}0.004 \\
\text { to } \\
0.048\end{array}$ & $0.015 \pm 0.019$ & $<0.001$ & $<<0.001$ & $\begin{array}{l}<0.001 \\
\text { to } \\
0.002\end{array}$ & $<0.001$ \\
\hline $\begin{array}{l}\text { NITRATE-NITRITE } \\
\text { NITROGEN }\end{array}$ & $\mathrm{mg} / 1$ & 10 & $\begin{array}{l}0.31 \\
\text { to } \\
2.1\end{array}$ & $1.0 \pm 0.8$ & $\begin{array}{l}0.47 \\
\text { to } \\
1.9\end{array}$ & $1.1 \pm 0.7$ & $\begin{array}{l}1.8 \\
\text { to } \\
2.2\end{array}$ & $2.0 \pm 0.1$ & $\begin{array}{l}1.0 \\
\text { to } \\
4.6\end{array}$ & $2.3 \pm 1.3$ \\
\hline $\begin{array}{l}\text { NITRITE } \\
\text { NITROGEN }\end{array}$ & $\mathrm{mg} / \mathrm{l}$ & (3) & $<0.01$ & $<<0.01$ & $<0.01$ & $<<0.01$ & $<0.01$ & $<<0.01$ & $<0.01$ & $<<001$ \\
\hline
\end{tabular}


TABLE 4

SUMMARY OF GROUND WATER ANALYSES - INORGANIC AND OTHER SELECTED PARAMETERS, CY 1993

(Page 2 of 2)

\begin{tabular}{|c|c|c|c|c|c|c|c|c|c|c|}
\hline \multirow{2}{*}{ PARAMETER } & \multirow{2}{*}{ UNITS } & \multirow{2}{*}{$\begin{array}{l}\text { CONCENTRATION } \\
\text { GUIDELINE }^{(1)}\end{array}$} & \multicolumn{2}{|c|}{$\begin{array}{c}\text { UPGRADIENT } \\
\text { (USGS WELLS 12, } 15 \& 17 \text { ) }\end{array}$} & \multicolumn{2}{|c|}{$\begin{array}{c}\text { SYSTEM } \\
\text { (NRF WELLS } 6 \& 7 \text { ) }\end{array}$} & \multicolumn{2}{|c|}{$\begin{array}{c}\text { ONSITE } \\
\text { (NRF WEUS 1, 2, 3, \& 4) }\end{array}$} & \multicolumn{2}{|c|}{$\begin{array}{c}\text { DOWNGRADIENT } \\
\text { (USGS 97, 98, 99, } 102 \& \text { INEL 1P) }\end{array}$} \\
\hline & & & RANGE & MEAN $\pm s^{(2)}$ & RANGE & MEAN $\pm s^{(2)}$ & RANGE & MEAN $\pm s^{(2)}$ & RANGE & MEAN $\pm s^{(2)}$ \\
\hline $\begin{array}{l}\text { ORGANIC } \\
\text { CARBON (TOTAL) }\end{array}$ & $\mathrm{mg} / \mathrm{l}$ & (3) & $\begin{array}{l}0.1 \\
\text { to } \\
1.7\end{array}$ & $0.4 \pm 0.4$ & $\begin{array}{l}0.1 \\
\text { to } \\
1.2\end{array}$ & $0.5 \pm 0.4$ & $\begin{array}{l}0.4 \\
\text { to } \\
1.9\end{array}$ & $0.8 \pm 0.4$ & $\begin{array}{l}0.2 \\
\text { to } \\
1.7\end{array}$ & $0.6 \pm 0.3$ \\
\hline $\begin{array}{l}\text { ORTHOPHOS- } \\
\text { PHATE } \\
\text { PHOSPHOROUS }\end{array}$ & $\mathrm{mg} / \mathrm{l}$ & (3) & $\begin{array}{l}0.01 \\
\text { to } \\
0.03\end{array}$ & $0.02 \pm 0.01$ & $\begin{array}{l}0.01 \\
\text { to } \\
0.08\end{array}$ & $0.04 \pm 0.03$ & $\begin{array}{c}0.02 \\
\text { to } \\
0.04\end{array}$ & $0.02 \pm 0.0$ & $\begin{array}{c}<0.01 \\
\text { to } \\
0.03\end{array}$ & $<0.02$ \\
\hline $\mathrm{pH}$ & $\mathrm{pH}$ & 6.5 to 8.5 & $\begin{array}{l}7.76 \\
\text { to } \\
8.19\end{array}$ & $7.96 \pm 0.15$ & $\begin{array}{l}7.76 \\
\text { to } \\
8.37\end{array}$ & $8.04 \pm 0.23$ & $\begin{array}{l}7.82 \\
\text { to } \\
7.96\end{array}$ & $7.89 \pm 0.05$ & $\begin{array}{l}7.61 \\
\text { to } \\
8.05\end{array}$ & $7.88 \pm 0.10$ \\
\hline SILVER & $\mathrm{mg} / \mathrm{l}$ & 0.1 & $<0.001$ & $<<0.001$ & $<0.001$ & $<<0.001$ & $<0.001$ & $<<0.001$ & $<0.001$ & $<<0.001$ \\
\hline SODIUM & $\mathrm{mg} / \mathrm{l}$ & (3) & $\begin{array}{l}5.6 \\
\text { to } \\
16\end{array}$ & $10 \pm 4$ & $\begin{array}{c}7.8 \\
\text { to } \\
100\end{array}$ & $46 \pm 48$ & $\begin{array}{l}13 \\
\text { to } \\
20\end{array}$ & $17 \pm 2$ & $\begin{array}{l}8.9 \\
\text { to } \\
18\end{array}$ & $14 \pm 3$ \\
\hline $\begin{array}{l}\text { SPECIFIC } \\
\text { CONDUCTANCE }\end{array}$ & $\mu \mathrm{mho} / \mathrm{cm}$ & (3) & $\begin{array}{l}289 \\
\text { to } \\
600\end{array}$ & $412 \pm 135$ & $\begin{array}{c}243 \\
\text { to } \\
1470\end{array}$ & $764 \pm 641$ & $\begin{array}{l}578 \\
\text { to } \\
664\end{array}$ & $624 \pm 29$ & $\begin{array}{l}398 \\
\text { to } \\
713\end{array}$ & $573 \pm 93$ \\
\hline SULFATE & $\mathrm{mg} / \mathrm{l}$ & 250 & $\begin{array}{l}18 \\
\text { to } \\
38\end{array}$ & $25 \pm 8$ & $\begin{array}{l}15 \\
\text { to } \\
250\end{array}$ & $84 \pm 111$ & $\begin{array}{l}40 \\
\text { to } \\
54\end{array}$ & $46 \pm 5$ & $\begin{array}{l}21 \\
\text { to } \\
230\end{array}$ & $46 \pm 47$ \\
\hline TEMPERATURE & ${ }^{\circ} \mathrm{C}$ & (3) & $\begin{array}{l}11.0 \\
\text { to } \\
13.5\end{array}$ & $12.1 \pm 0.7$ & $\begin{array}{l}11.5 \\
\text { to } \\
15.0\end{array}$ & $13.3 \pm 1.4$ & $\begin{array}{c}10.0 \\
\text { to } \\
14.0\end{array}$ & $11.8 \pm 0.8$ & $\begin{array}{l}10.5 \\
\text { to } \\
12.5\end{array}$ & $11.6 \pm 0.5$ \\
\hline
\end{tabular}

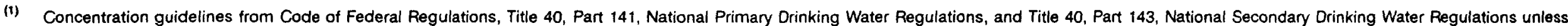
otherwise stated. Drinking water standards are used as a guide at NRF for monitoring ground water. Used for comparison only.

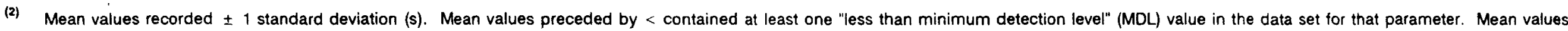
preceded by < < contained all "less than minimum detection level" values in the data set for that parameter and were the average of the MDLs.

(3) No guideline available per federal or state regulations. 
TABLE 5

SUMMARY OF DRINKING WATER RADIOACTIVITY RESULTS, CY $1993^{11,21}$

\begin{tabular}{|c|c|c|c|}
\hline NRF WELL \#1 & GROSS ALPHA $\times 10^{-8} \mu \mathrm{CI} / \mathrm{mI}^{(3)}$ & GROSS BETA $\times 10^{-\theta} \mu \mathrm{Cl} / \mathrm{mI}^{(4)}$ & TRITIUM $\times 10^{-7} \mu \mathrm{Cl} / \mathrm{ml}$ \\
\hline Minimum & $0.3 \pm 0.8$ & $-1.0 \pm 2.0$ & $-1.8 \pm 1.7$ \\
\hline Maximum & $2.4 \pm 1.1$ & $4.0 \pm 2.0$ & $2.0 \pm 2.0$ \\
\hline Mean & $1.0 \pm 0.9$ & $1.7 \pm 2.0$ & $0.3 \pm 1.8$ \\
\hline
\end{tabular}

NRF WELL \#2

\begin{tabular}{||l|c|c|c||}
\hline Minimum & $0.2 \pm 0.8$ & $-2.0 \pm 2.0$ & $-0.8 \pm 1.7$ \\
\hline Maximum & $2.4 \pm 1.1$ & $3.0 \pm 2.0$ & $1.0 \pm 1.7$ \\
\hline Mean & $1.1 \pm 0.9$ & $1.0 \pm 2.0$ & $0.2 \pm 1.9$ \\
\hline
\end{tabular}

NRF WELL \#3

\begin{tabular}{|l|c|c|c|}
\hline Minimum & $-0.3 \pm 0.7$ & $-2.0 \pm 2.0$ & $-1.1 \pm 1.7$ \\
\hline Maximum & $1.7 \pm 0.9$ & $5.0 \pm 2.0$ & $1.2 \pm 1.7$ \\
\hline Mean & $1.0 \pm 0.9$ & $1.4 \pm 2.0$ & $0.0 \pm 1.9$ \\
\hline
\end{tabular}

NRF WELL \#4

\begin{tabular}{||l|c|c|c||}
\hline Minimum & $-0.3 \pm 0.7$ & $-1.1 \pm 2.0$ & $-1.1 \pm 1.7$ \\
\hline Maximum & $2.8 \pm 1.2$ & $4.0 \pm 2.0$ & $2.0 \pm 2.0$ \\
\hline Mean & $1.0 \pm 0.9$ & $1.2 \pm 2.0$ & $0.5 \pm 1.9$ \\
\hline
\end{tabular}

(1) Uncertainties for random counting error were stated \pm 1 sigma level, 1 s. Results less than or equal to $2 s$ were interpreted as including "zero" or as not detected. For results greater than $2 \mathrm{~s}$ but less than or equal to $3 \mathrm{~s}$, detection was questionable. Results greater than $3 s$ indicated detection. Negative results indicate sample counts were less than background.

(2) All radioactivity levels for gross alpha and tritium were below the limits of $1.5 \times 10^{-8} \mu \mathrm{Ci} / \mathrm{ml}$ and $2.0 \times 10^{6} \mu \mathrm{Ci} / \mathrm{ml}$ respectively, per Reference 2. All radioactivity levels for gross beta were below the limit of $8 \times 10^{-9} \mu \mathrm{Ci} / \mathrm{ml}$ per Reference 2 for strontium-90.

(3) Analyses use plutonium-239 as a reference source.

(4) Based on cesium-137. Comparatively, cesium-137 contributes less dose to any internal organ than the equivalent concentration of strontium-90. Therefore, using the strontium-90 limit for cesium-137 concentrations provides a conservative limit for internal organ dose. 
TABLE 6

SUMMARY OF GROUND WATER RADIOACTIVITY RESULTS, CY $1993^{(1,2)}$ (USGS LABORATORY)

\begin{tabular}{|c|c|c|}
\hline UP GRADIENT & GROSS ALPHA $\times 10^{\circ} \mu \mathrm{Cl} / \mathrm{ml}^{(3)}$ & GROSS BETA $\times 10^{\circ} \mu \mathrm{Cl} / \mathrm{ml}^{(4)}$ \\
\hline Minimum & $1.3 \pm 0.3$ & $1.2 \pm 0.3$ \\
\hline Maximum & $3.8 \pm 1.0$ & $3.0 \pm 0.8$ \\
\hline Mean & $2.2 \pm 0.6$ & $2.3 \pm 0.4$ \\
\hline
\end{tabular}

SYSTEM

\begin{tabular}{||l|l|l|}
\hline Minimum & $0.9 \pm 0.4$ & $2.7 \pm 0.5$ \\
\hline Maximum & $4.2 \pm 1.9$ & $6.8 \pm 1.0$ \\
\hline Mean & $2.1 \pm 1.0$ & $4.5 \pm 0.8$ \\
\hline
\end{tabular}

ONSITE

\begin{tabular}{|l|l|l|}
\hline \hline Minimum & $1.0 \pm 0.5$ & $2.4 \pm 0.4$ \\
\hline Maximum & $5.0 \pm 1.1$ & $3.6 \pm 0.5$ \\
\hline Mean & $3.1 \pm 0.8$ & $2.9 \pm 0.5$ \\
\hline
\end{tabular}

DOWN GRADIENT

\begin{tabular}{||l|l|l|}
\hline \hline Minimum & $1.3 \pm 0.6$ & $1.8 \pm 0.4$ \\
\hline Maximum & $4.2 \pm 1.0$ & $4.0 \pm 0.6$ \\
\hline Mean & $2.5 \pm 0.7$ & $2.7 \pm 0.4$ \\
\hline
\end{tabular}

(1) Uncertainties for random counting error were stated \pm 1 sigma level, 1 s. Results less than or equal to 2 s were interpreted as including "zero" or as not detected. For results greater than 2 s but less than or equal to $3 s$, detection was questionable. Results greater than 3 s indicated detection.

(2) All gross alpha radioactivity levels were below the limit of $1.5 \times 10^{-8} \mu \mathrm{Ci} / \mathrm{ml}$ per Reference 2 . All radioactivity levels for gross beta were below the limit of $8 \times 10^{-9} \mu \mathrm{Cj} / \mathrm{ml}$ per Reference 2 for strontium-90.

(3) Based on dissolved thorium-230.

(4) Based on dissolved strontium-90. 


\section{AIRBORNE EFFLUENT MONITORING}

The purpose of the airborne effluent monitoring program is to determine the effectiveness of control methods and to measure concentrations of air pollutants released from NRF for comparison with applicable standards and natural background levels.

\section{Sources and Treatment}

The principal sources of nonradioactive industrial gaseous effluents are air from offices, water vapor from cooling towers, and fuel combustion products from the three steam generating boilers. Number 5 fuel oil is utilized in boiler operation, and the resulting combustion gas products are released through elevated exhaust stacks. The boilers provide steam primarily for heating and, therefore, are in maximum use during the colder months. Other facilities at NRF such as a paint shop, chemistry laboratories, a carpenter shop, a welding shop, and emergency power diesel generators also constitute point sources of airborne effluents. All of these sources contribute to particulate matter present in the ambient air. However, the primary source of airborne particulate matter at NRF is windblown dust from the desert floor surrounding the facility (Reference 1).

Asbestos containing material (ACM) is present at NRF primarily in pipe insulation. Small amounts of ACM have also been identified in floor tiles and mastic, in fire resistive safes and in gasket materials. NRF has identified and labeled all known asbestos-containing thermal insulation onsite. A longterm asbestos abatement plan is in place to reduce the amount of asbestos on the NRF Site. Major asbestos abatement projects performed in 1993 included the removal of friable asbestos in fifteen buildings at NRF.
Small quantities of radioactivity are contained in the airborne effluent from prototype plant operations and work performed at ECF. High efficiency particulate air (HEPA) filters and charcoal filters are used on select exhaust stacks to reduce radioactive air emissions. Naturally occurring radon present in the environment is also present in the exhaust air.

\section{Monitoring and Analyses}

- Nonradiological: Emissions from the steam generating boiler units were calculated using the sulfur content of the fuel oil and EPA approved emission factors. These calculations provided values for the amount of sulfur oxides, nitrogen oxides and particulate matter emitted as a result of boiler operations.

The fuel oil consumed at NRF conformed to the State of Idaho standard for sulfur content as confirmed by vendor data. Calculated per Reference 3, annual emissions for 1993 were 18.2 tons of nitrogen oxides expressed as nitrogen dioxide, 39.6 tons of sulfur oxides and 3.4 tons of particulate matter.

The DOE-RESL laboratory inputs the calculated emissions of sulfur oxides and nitrogen oxides into an air dispersion model. The air dispersion model accounts for meteorological conditions such as wind speed, wind direction, and rainfall when calculating average annual concentrations for air pollutants. DOE-RESL calculates the maximum average annual sulfur dioxide and nitrogen dioxide concentrations at the INEL Site boundary from all INEL sources including NRF. These values are reported in the annual Idaho National Engineering Laboratory Site Environmental Report. 
In addition, DOE-RESL operates twenty-three air monitors at the INEL and the surrounding communities to determine the concentration of particulate matter in the air. The measured concentration is referred to as total suspended particulates. The total suspended particulate concentrations measured on the NRF Site ranged from 3 to 35 micrograms per cubic meter of air, which were less than the State of Idaho maximum ambient air quality standards for total suspended particulates of 75 micrograms per cubic meter (primary standard) and 60 micrograms per cubic meter (secondary standard) (Reference 4). Results of DOERESL air monitoring are also recorded in the annual Idaho National Engineering Laboratory Site Environmental Report.

The EPA has national primary and secondary ambient air quality standards for small particulate matter, particulates less than or equal to 10 micrometers in diameter $\left(P M_{10}\right)$, of 50 micrograms per cubic meter of air (Reference 7). Because this small particulate matter is only a portion of the total suspended particulates measured, the concentration of small particulates at NRF was less than the measured 3 to 35 micrograms of total suspended particles per cubic meter of air. Therefore, NRF also met the EPA standard for small particulate matter.

Four diesel generators are operated at the NRF Site under a permit to construct exemption issued by the State of Idaho which allows each of the diesels to be operated 228 hours per year. Each diesel generator was operated less than 228 hours in 1993 in compliance with the State of Idaho requirements.

Whenever work was being performed that could result in airborne asbestos, sampling in or near the worksite was performed by drawing a measured volume of air through filter paper. Samples were analyzed locally using phase contrast microscopy or were analyzed by outside laboratories using transmission electron microscopy. NRF's ongoing area monitoring program has confirmed that workers in spaces containing asbestos materials were not exposed to asbestos fibers above regulatory limits. Area samples and personal monitoring devices have also shown that engineering controls in place were effective. This sampling verified there were no measurable discharges of asbestos fibers to the environment. All asbestos work performed at NRF was conducted in accordance with federal regulatory requirements.

Additional information concerning air emission estimating methods and monitoring locations is contained in the annual update of the INEL Air Emissions Inventory.

- Radiological: Airborne effluents from the radiological facilities at NRF were monitored for particulate radioactivity by the use of fixed filter air samplers. Air discharged from exhaust stacks was continuously drawn through a filter for a period of a month. The filters were then analyzed for radioactivity with a low-background alpha-beta counter. Filters that exceeded the control level of $2 x$ $10^{-14}$ microcuries per milliliter of air were also analyzed using a gamma spectrometer to confirm that the radioactivity was due to naturally occurring radiation.

Tritium sampling was conducted at five NRF locations. The tritium samplers used silica gel to absorb water vapor from exhaust stack effluents. The absorbed water was subsequently recovered and analyzed. In addition to this method of tritium sampling, a monthly tritium analysis of water pit water from ECF was used to calculate monthly emissions of tritium via evaporation.

Fixed filter air and tritium samplers were located at the NRF gatehouse. These samplers measured ambient radioactivity levels at NRF for comparison with facility exhaust levels. 
The quantities of gaseous argon- 41 and carbon-14 radioactivity in the effluent air were calculated based on reactor plant operating parameters, evaporation rates from the ECF water pits, and fuel handling operations. In addition, at ECF, charcoal cartridges were used to sample for radioiodine in airborne effluent from the facility. These charcoal cartridges were periodically replaced and promptly counted using gamma spectrometry for quantitative identification.

The radioactivity contained in the exhaust air during 1993 consisted of: (1) 0.000067 curie of particulate fission and activation products having half-lives greater than one day, (2) 0.32 curie of noble gases with half-lives less than 12 days, principally argon-41, (3) 0.067 curie of tritium, (4) 0.91 curie of carbon-14, and (5) 0.0000046 curie of iodine-131. Data and analysis results that indicate the average concentration and total amount of airborne radioactivity are reported via the INEL Radioactive Waste Management System.

An effective dose equivalent of 0.00062 millirem per year from NRF air emissions was calculated for the maximally exposed members of the general public. This calculation was performed using CAP-88, the EPA approved computer model (Reference 6). This is 0.006 percent of the EPA's standard of 10 millirem per year for exposure of a member of the general public to airborne radioactivity (Reference 7 ).
Information regarding airborne radioactivity and effective dose calculations is also contained in the INEL National Emission Standard for Hazardous Air Pollutants Annual Report.

\section{Airborne Effluent Monitoring Conclusions}

- Nonradiological: Air emissions from NRF did not exceed the applicable air quality standards set by the EPA and the State of Idaho. Small particulates and total suspended particulates were less than applicable standards. All asbestos removal work was completed in compliance with the applicable requirements with no measurable discharge of asbestos fibers to the environment.

- Radiological: The results of NRF's airborne radiological effluent monitoring for 1993 have shown that the amount of radioactivity released was too small to result in any measurable change in the background radioactivity levels in the environment. The concentrations of the particulate and gaseous radioactivity released from the NRF Site during 1993 were well within the applicable standards for radioactivity in the environment. Furthermore, the estimated radiation dose to any member of the general public from the airborne radioactivity released was too low to measure and was conservatively calculated to be significantly below the standard established by the EPA. 
This page intentionally left blank. 


\section{ENVIRONMENTAL RADIOLOGICAL MONITORING}

The environmental radiological monitoring program has two purposes. The first is to determine whether current NRF operations are adding any radioactivity to the environment on or around the NRF Site. The second purpose is to verify continued containment of the few areas around the site known to contain residual low-level radioactivity from past operations.

\section{Sources}

In accordance with standard practices at the time, and in full compliance with existing regulations, water containing low levels of radioactivity was discharged to specific, defined areas on NRF property during past operations. This practice was discontinued in 1979 when onsite facilities for recycling water containing trace amounts of radioactivity became operational. There are several localized areas of soil within NRF's area of responsibility, such as the A1W West Seepage Basin and the S1W South Seepage Basin, that contain small amounts of residual radioactivity, principally cobalt-60 and cesium-137 from past operations. These areas are not accessible to members of the general public and are surveyed on a routine basis to verify that the radioactivity is not migrating.

\section{Monitoring and Analyses}

Soil samples were collected periodically from the areas surrounding the $A 1 W$ and SiW Seepage Basins, the IWD, from all areas where residual radioactivity from past operations was known to have been discharged or had the potential to have been inadvertently discharged and areas downwind of exhaust stacks. Sediment samples were collected from the A1W and S5G Cooling Towers, the Sewage Lagoon and the IWD. The sample collection points are illustrated in Figure 4.
Vegetation growing in and around the A1W and S1W Seepage Basins and areas downwind from exhaust stacks was collected at the same locations as the routine soil samples. The vegetation samples along the IWD were collected adjacent to but outside of the ditch bed. Analyses of these samples were performed with a gamma spectrometry system.

The results of the soil, vegetation and sediment sample analyses are summarized in Table 7. All soil samples collected from areas known to contain residual radioactivity from historic operations, with one exception, were well below local control levels of 30 picocuries per gram. One sample containing 39 picocuries per gram of cobalt- 60 and 524 picocuries per gram of cesium-137 was obtained in a controlled area near the S1W seepage basin. However, all areas containing residual radioactivity, including the S1W seepage basin are not accessible to the general public and are surveyed on a routine basis to verify that the radioactivity is not migrating. The basin is included in the scope of remediation activities under the INEL FFA/CO and work is scheduled to begin in the future.

Gamma analyses of the vegetation samples showed no detectable cobalt-60 and up to 66.0 picocuries per gram of cesium-137. A person would consume over 67 pounds of material containing the highest measured levels each year before exceeding the dose permitted a member of the general public by the Nuclear Regulatory Commission (NRC).

\section{Environmental Radiological Monitoring Conclusions}

NRF operations in 1993 did not contribute to any measurable increase in radiation levels in the surrounding environment. The localized areas at NRF that contain low 
levels of residual radioactivity from past operations continue to be adequately controlled and contained to prevent migration. This radioactivity does not present any significant risk to NRF personnel, the general public or the environment. 


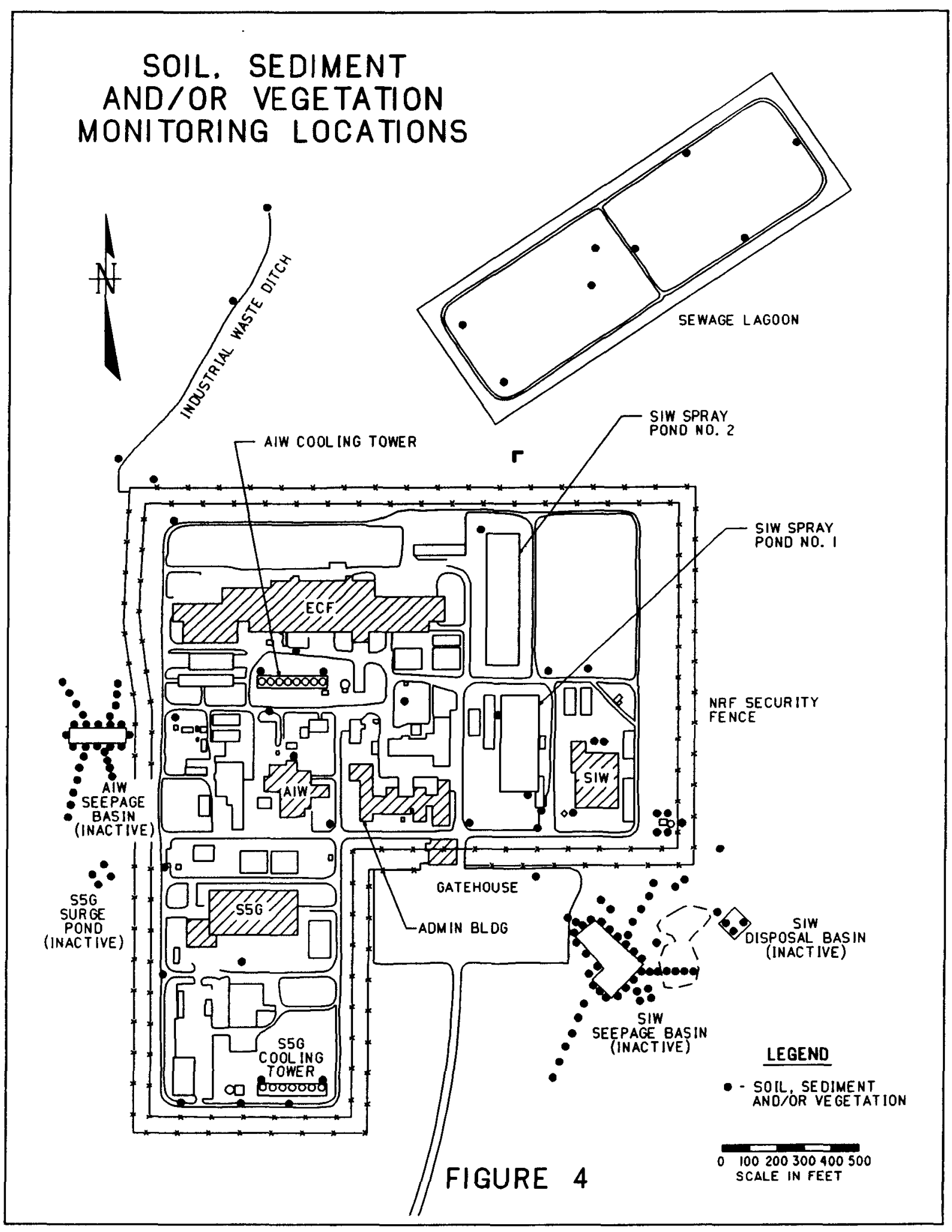


TABLE 7

SUMMARY OF SOIL, SEDIMENT AND VEGETATION GAMMA RADIOACTIVITY RESULTS, CY $1993^{\text {(1) }}$ pCi/gram Dry Weight

(Page 1 of 2)

\begin{tabular}{|c|c|c|c|c|c|c|c|c|c|c|c|c|}
\hline \multirow[b]{3}{*}{ Area } & \multicolumn{6}{|c|}{ Cobalt-60 } & \multicolumn{6}{|c|}{ Cesium-137 } \\
\hline & \multicolumn{2}{|c|}{ Soil } & \multicolumn{2}{|c|}{ Vegetation } & \multicolumn{2}{|c|}{ Sediment } & \multicolumn{2}{|c|}{ Soil } & \multicolumn{2}{|c|}{ Vegetation } & \multicolumn{2}{|c|}{ Sediment } \\
\hline & Mean & Range & Mean & Range & Mean & Range & Mean & Range & Mean & Range & Mean & Range \\
\hline $\begin{array}{l}\text { A1W } \\
\text { Seepage Basin } \\
\text { (Inactive) } \\
\end{array}$ & $<0.5$ & $\begin{array}{c}<0.1 \\
\text { to } \\
4.1 \pm 0.3\end{array}$ & $<<0.1$ & $\begin{array}{l}<0.2 \\
\text { to } \\
<1.2\end{array}$ & - & - & $<3.5$ & $\begin{array}{c}<0.1 \\
\text { to } \\
22.3 \pm 0.4\end{array}$ & $<<0.5$ & $\begin{array}{l}<0.2 \\
\text { to } \\
<1.2\end{array}$ & - & - \\
\hline $\begin{array}{l}\text { S1W Seepage } \\
\text { Basin (3) } \\
\text { (Inactive) }\end{array}$ & $<0.7$ & $\begin{array}{c}<0.1 \\
\text { to } \\
5.0 \pm 0.4 \\
\end{array}$ & $<<0.1$ & $\begin{array}{c}<0.1 \\
\text { to } \\
<0.3 \\
\end{array}$ & - & -- & $<4.0$ & $\begin{array}{c}<0.1 \\
\text { to } \\
18.0 \pm 0.5\end{array}$ & $<1.9$ & $\begin{array}{c}<0.1 \\
\text { to } \\
66.0 \pm 1.5 \\
\end{array}$ & -- & - \\
\hline $\begin{array}{l}\text { Industrial } \\
\text { Waste Ditch }^{(4)}\end{array}$ & $<<0.1$ & $<0.1$ & $<<0.2$ & $\begin{array}{c}<0.1 \\
\text { to } \\
<0.2 \\
\end{array}$ & $<<0.1$ & $<0.1$ & $<<0.1$ & $<0.1$ & $<<0.1$ & $\begin{array}{c}<0.1 \\
\text { to } \\
<0.2 \\
\end{array}$ & $<0.2$ & $\begin{array}{c}<0.1 \\
\text { to } \\
0.4 \pm 0.1 \\
\end{array}$ \\
\hline $\begin{array}{l}\text { Downwind of } \\
\text { Exhaust Stacks }\end{array}$ & $<<0.2$ & $\begin{array}{l}<0.1 \\
\text { to } \\
<0.9\end{array}$ & $<<0.2$ & $\begin{array}{c}<0.1 \\
\text { to } \\
<0.3\end{array}$ & - & - & $<2.2$ & $\begin{array}{c}<0.4 \\
\text { to } \\
8.1 \pm 0.5\end{array}$ & $<<0.2$ & $\begin{array}{l}<0.1 \\
\text { to } \\
<0.2\end{array}$ & - & - \\
\hline $\begin{array}{l}\text { Known Areas of } \\
\text { Residual } \\
\text { Radioactivity }(8, n)\end{array}$ & $<2.0$ & $\begin{array}{c}<0.1 \\
\text { to } \\
39.0 \pm 1.0\end{array}$ & -- & - & - & - & $<22.4$ & $\begin{array}{c}<0.1 \\
\text { to } \\
524.0 \pm 3.1\end{array}$ & - & - & - & - \\
\hline $\begin{array}{l}\text { Inactive } \\
\text { Pipelines }\end{array}$ & 0.1 & $0.1 \pm 0.1$ & $\cdots$ & - & - & - & 0.6 & $\begin{array}{c}0.2 \pm 0.1 \\
\text { to } \\
0.9 \pm 0.2\end{array}$ & - & $\cdots$ & $\ldots$ & - \\
\hline $\begin{array}{l}\text { A1W Cooling } \\
\text { Tower }^{(9)}\end{array}$ & - & -- & -- & -- & $<0.2$ & $\begin{array}{c}<0.1 \\
\text { to } \\
0.4 \pm 0.1 \\
\end{array}$ & -- & -- & - & - & $<0.2$ & $\begin{array}{c}<0.1 \\
\text { to } \\
0.4 \pm 0.1\end{array}$ \\
\hline $\begin{array}{l}\text { S5G Cooling } \\
\text { Tower }^{(9)}\end{array}$ & $\cdots$ & $\cdots$ & -- & - & $<<0.5$ & $<0.5$ & $\cdots$ & $\cdots$ & -- & - & $<<0.3$ & $<0.3$ \\
\hline
\end{tabular}


TABLE 7

SUMMARY OF SOIL, SEDIMENT AND VEGETATION GAMMA RADIOACTIVITY RESULTS, CY $1993^{(1}$

pCi/gram Dry Weight

(Page 2 of 2)

\begin{tabular}{|c|c|c|c|c|c|c|c|c|c|c|c|c|}
\hline \multirow[b]{3}{*}{ Avea } & \multicolumn{6}{|c|}{ Cobalt-60 } & \multicolumn{6}{|c|}{ Cesium-137 } \\
\hline & \multicolumn{2}{|c|}{ Soll } & \multicolumn{2}{|c|}{ Vegetation } & \multicolumn{2}{|c|}{ Sediment } & \multicolumn{2}{|c|}{ Soil } & \multicolumn{2}{|c|}{ Vegetation } & \multicolumn{2}{|c|}{ Sediment } \\
\hline & Mean & Range & Mean & Range & Mean & Range & Mean & Range & Mean & Range & Mean & Range \\
\hline $\begin{array}{l}\text { Southwest } \\
\text { Sewage } \\
\text { Lagoon }{ }^{(10)}\end{array}$ & $\cdots$ & $\ldots$ & - & - & 06 & $\begin{array}{c}01 \pm 01 \\
\text { to } \\
15 \pm 01\end{array}$ & - & - & - & $\cdots$ & 14 & $\begin{array}{c}06 \pm 01 \\
\text { to } \\
3.0 \pm 03\end{array}$ \\
\hline $\begin{array}{l}\text { Northeast } \\
\text { Sewage } \\
\text { Lagoon }{ }^{(10)}\end{array}$ & -- & $\cdots$ & - & - & 0.02 & $\begin{array}{c}0.00 \pm 0.02 \\
\text { to } \\
0.06 \pm 0.03\end{array}$ & $\ldots$ & - & - & - & 054 & $\begin{array}{c}013 \pm 002 \\
\text { to } \\
100 \pm 012\end{array}$ \\
\hline
\end{tabular}

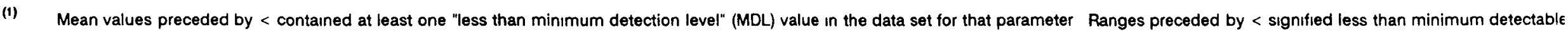

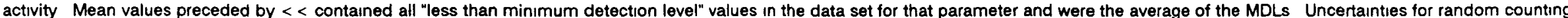

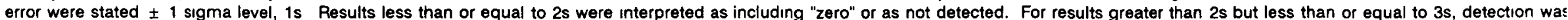
questionable Results greater than 3 indicated detection.

(2) Ranges were for 32 samples of soll and 27 of vegetation.

(3) Ranges were for 39 samples each of soil and vegetation.

(4) Ranges were for 14 samples of soil, 7 samples of vegetation and 7 samples of sediment

(5) Ranges were for 10 samples each of soll and vegetation

(8) Ranges were for 32 samples of soll

(7) The highest measured residual radıoactivity was located in a controlled area adjacent to the S1W Seepage Basın

(8) Ranges were for 2 samples of soll

(9) Ranges were for 2 samples of sediment

(10) Ranges were for 4 samples of sedıment 
NRF 1992 Environmental Monitoring Report

This page intentionally left blank. 


\section{RADIATION MONITORING}

The purpose of the radiation monitoring program is to verify that NRF operations do not increase radiation exposure to the general public.

\section{Monitoring and Analysis}

Direct measurement of radiation along the security fence was performed independently by NRF and the DOE-RESL. The NRF radiation monitoring program involves measuring ionizing radiation levels at 17 locations along the site security fence and eight other locations within the NRF property boundaries (Figure 5). Standard Navy calcium-fluoride thermoluminescent dosimeters (TLDs) were placed at each location approximately one meter above the ground. These environmental TLDs are calibrated to a known source value. Figure 5 shows the locations of 23 of the posted NRF TLDs. The two remaining TLDs, 17 and 18, were located near the NRF Sewage Lagoon. NRF also posted 15 TLDs (three groups of five) throughout the INEL varying from five to ten miles from the NRF Site to determine INEL radiation background levels. All NRF environmental TLDs were collected and processed quarterly using an automated TLD processing system.

The DOE-RESL measured ionizing neutron radiation levels at 11 points surrounding the NRF Site. This monitoring was performed by placing five individual lithium-fluoride TLD chips one meter above the ground at predesignated locations. Figure 5 depicts the locations of the DOE-RESL dosimeters. DOE uses TLD measurements obtained from seven distant communities to determine natural background ionizing radiation levels. The locations of these offsite monitoring points are shown in Figure 6.
The DOE-RESL environmental TLDs were collected and processed every six months. In addition to the TLD network, radiation surveys were conducted around the site perimeter using a highly sensitive radiation detection instrument.

\section{Radiation Monitoring Conclusions}

The results of the radiation monitoring programs conducted by NRF and DOERESL are summarized in Table $8 . \quad A$ comparison of the average reading along the NRF security fence and the average background reading measured by NRF at locations on the INEL 5 to 10 miles away from NRF indicates that NRF does not contribute to an increase in radiation levels. This is further verified by comparing the average NRF security fence reading to the average distant community reading. The slight variations in the values are not significant and were due to the variables inherent in dosimeter processing, location and dosimeter types used by the NRF and RESL radiation monitoring programs.

Some TLD monitoring locations on the NRF Site were located near known individual sources of radiation around the site, and as expected, record exposure higher than the natural background levels measured offsite. None of these TLDs showed any notable increase in exposure compared to previous monitoring periods. Even though these readings were higher than the NRF average environmental radiation level, the radiation levels were localized and do not contribute to increased radiation exposure to the general public. 


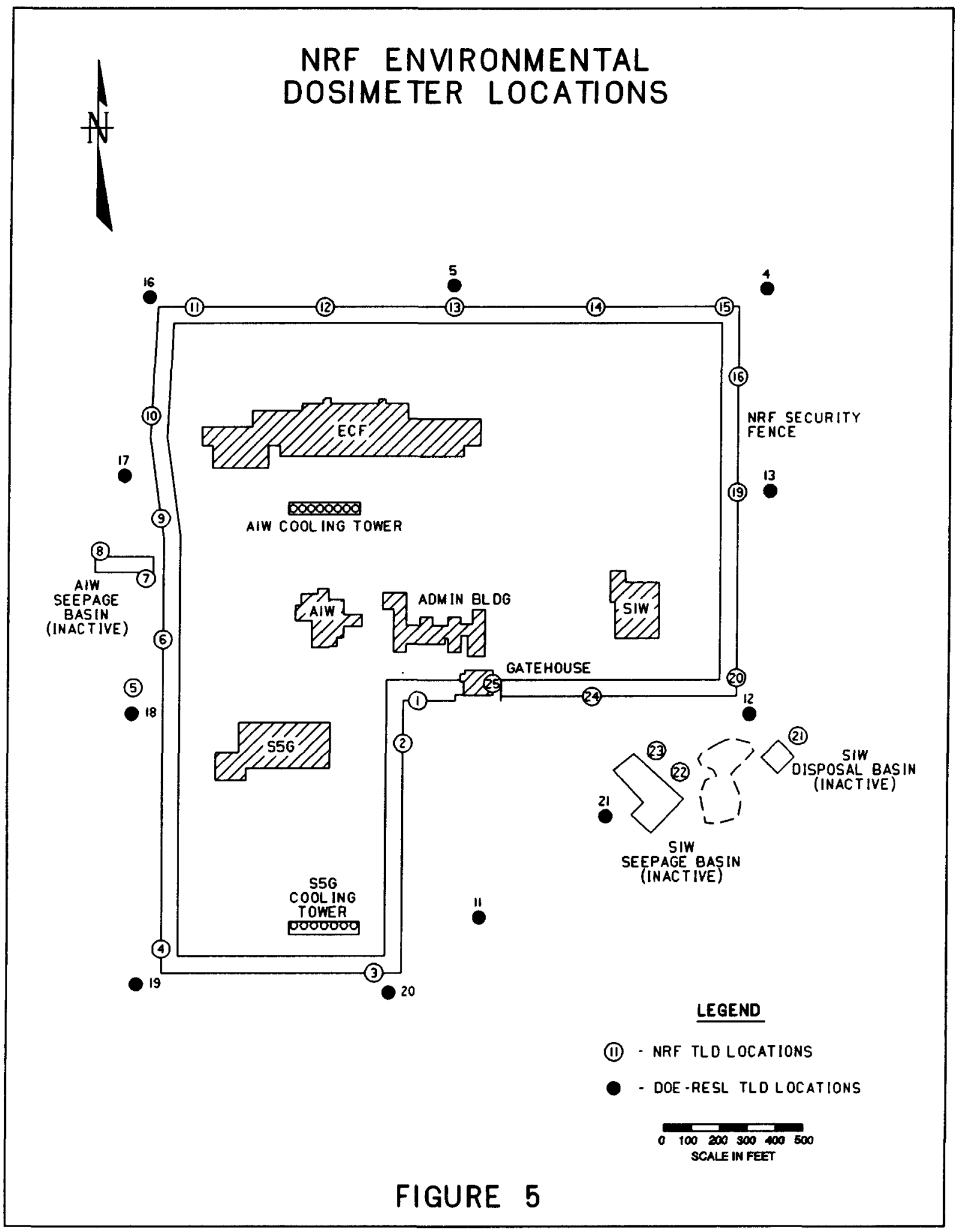




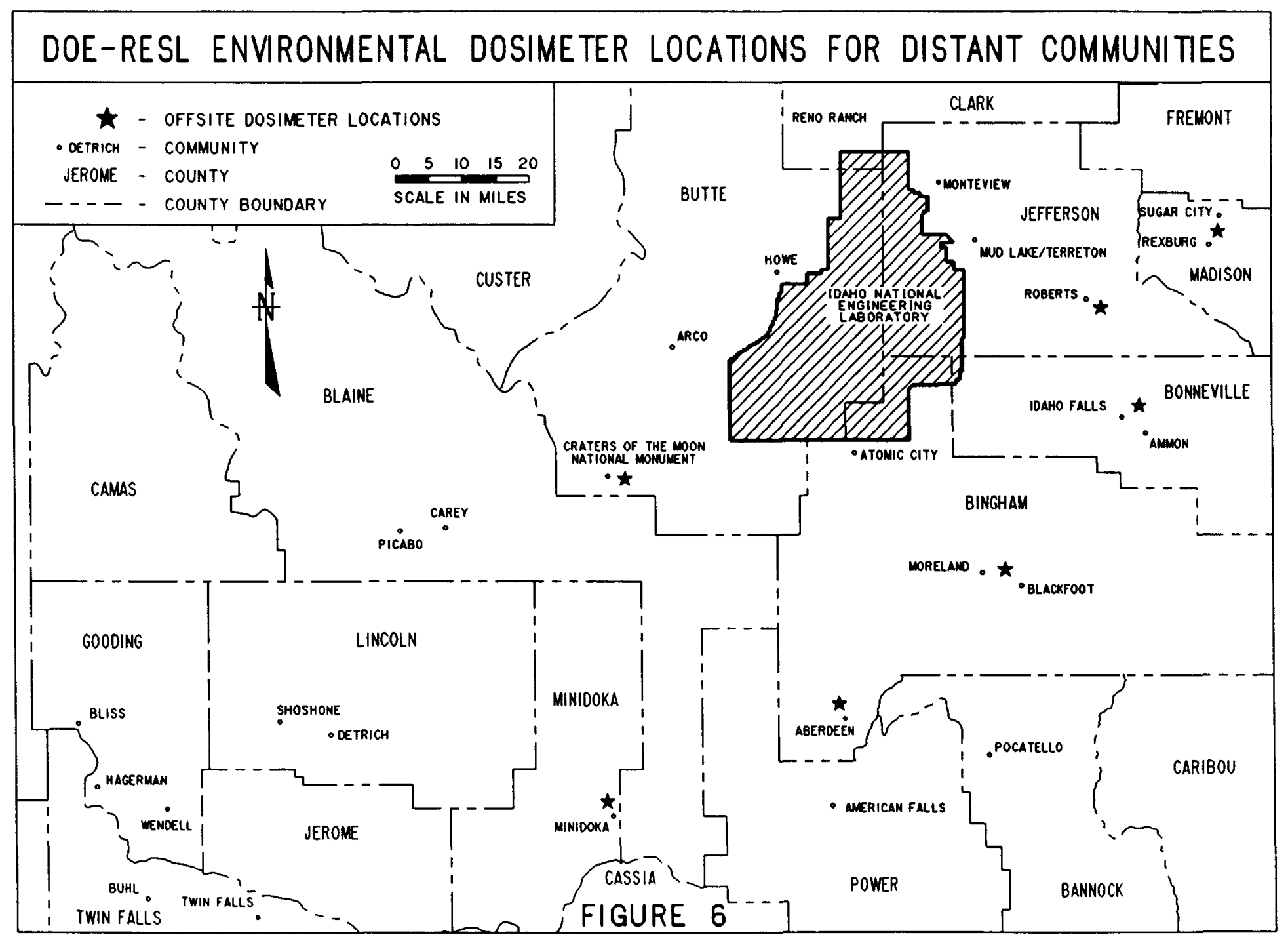




\section{TABLE 8 \\ ENVIRONMENTAL IONIZING RADIATION MEASUREMENTS \\ FOR THE NAVAL REACTORS FACILITY, CY 1993 \\ Millirem per Calendar Quarter}

\begin{tabular}{|c|c|c|c|c|c|c|c|c|c|c|c|c|c|c|c|c|}
\hline 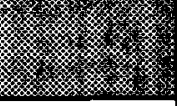 & \multicolumn{4}{|c|}{ NRF Onsite Readings (1) } & \multicolumn{4}{|c|}{ DOE-RESL Readings of NRF Site } & \multicolumn{4}{|c|}{$\begin{array}{l}\text { NRF Readings of INEL Background } \\
\text { Remote from NRF (1) }\end{array}$} & \multicolumn{4}{|c|}{$\begin{array}{l}\text { DOE-RESL Readings from Distant } \\
\text { Communities }\end{array}$} \\
\hline $\begin{array}{l}\text { Monitoring } \\
\text { Period }\end{array}$ & $\begin{array}{l}\text { Number of } \\
\text { Measure- } \\
\text { ments }\end{array}$ & Mean (2) & Max. & Min. & $\begin{array}{c}\text { Number of } \\
\text { Measure- } \\
\text { ments }\end{array}$ & Mean ${ }^{(3)}$ & Max. & Min. & $\begin{array}{l}\text { Number of } \\
\text { Measure- } \\
\text { ments }\end{array}$ & Mean (4) & Max. & Min. & $\begin{array}{l}\text { Number of } \\
\text { Measure- } \\
\text { ments }\end{array}$ & Mean (5) & Max. & Min. \\
\hline 1st & 25 & $25 \pm 3$ & 33 & 19 & \multirow[t]{2}{*}{11} & \multirow[t]{2}{*}{$64 \pm 2$} & \multirow[t]{2}{*}{70} & \multirow[t]{2}{*}{60} & 14 & $24 \pm 2$ & 27 & 20 & \multirow[t]{2}{*}{6} & \multirow[t]{2}{*}{$52 \pm 2$} & \multirow[t]{2}{*}{55} & \multirow[t]{2}{*}{48} \\
\hline 2nd & 25 & $30 \pm 3$ & 41 & 26 & & & & & 15 & $30 \pm 3$ & 33 & 28 & & & & \\
\hline 3rd & 25 & $28 \pm 3$ & 35 & 24 & \multirow[t]{2}{*}{11} & \multirow[t]{2}{*}{$72 \pm 4$} & \multirow[t]{2}{*}{78} & \multirow[t]{2}{*}{69} & 15 & $29 \pm 3$ & 31 & 25 & \multirow[t]{2}{*}{6} & \multirow[t]{2}{*}{$60 \pm 3$} & \multirow[t]{2}{*}{69} & \multirow[t]{2}{*}{51} \\
\hline 4 th & 25 & $32 \pm 3$ & 40 & 27 & & & & & 15 & $31 \pm 3$ & 37 & 27 & & & & \\
\hline
\end{tabular}

(1) All radiation exposure readings are in millirem and have been normalized to a 91.5 day calendar quarter.

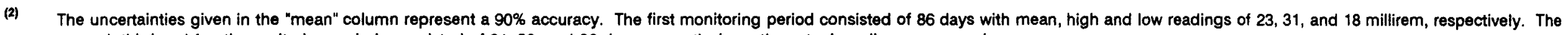
second, third and fourth monitoring periods consisted of 91,92 , and 92 days respectively so the actual readings were used.

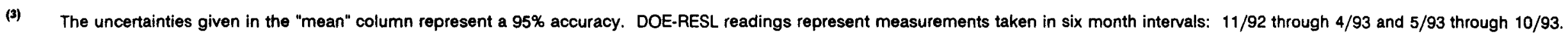

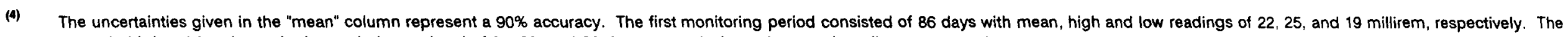
second, third and fourth monitoring periods consisted of 91,92 , and 92 days respectively so the actual readings were used.

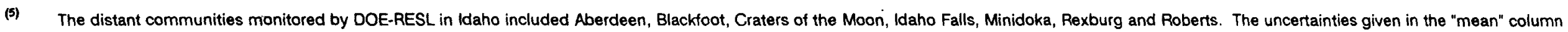

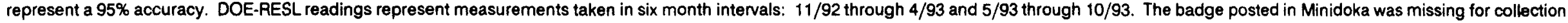
at both monitoring intervals. 


\section{ASSESSMENT OF RADIATION DOSE-TO-MAN}

Environmental monitoring results from 1993 did not reveal any measurable increase in the naturally occurring radioactivity levels in the environment from NRF operations. Radiation exposure to the general public from NRF airborne emissions was too low to measure and could only be determined with conservative calculational models based on the effluent radioactivity data. Therefore, an assessment of the radiation dose-to-man was performed by analyzing the exposure pathways whereby radioactivity might theoretically be transported from NRF to the general public. The following potential exposure pathways were considered in this assessment:

\section{- Liquid Pathways}

Ingestion of radioactivity in the drinking water supply.

\section{- Airborne Pathways}

Exposure as a result of radionuclide emissions to the air.

\section{- Direct Exposure Pathways}

Direct external radiation from NRF operations.

The dose for each exposure pathway was explicitly calculated for each radionuclide and applicable daughter products. There is no exposure to the public from liquid pathways because, as in previous years, NRF did not discharge any radioactive liquid in 1993. The effective dose equivalent for airborne path-ways was calculated using the EPA approved CAP-88 computer program described in Reference 6 . The airborne pathway calculations used 1993 wind speed and direction data collected by the National Oceanic and Atmospheric Administration (NOAA) at NRF and average meteorological data measured by the INEL meteorological observation network. Because the radiation levels at the NRF site boundary are low, and the site is removed from public access, there is no exposure to the public from direct exposure pathways.

The maximum effective dose equivalent which a member of the public could have hypothetically received due to NRF operations in 1993 as shown in Table 9 was 0.00062 millirem. The maximum potential dose of 0.00062 millirem per year is substantially below the radiation exposure limits of 100 millirem per year established by the Nuclear Regulatory Commission and the Department of Energy. Further, it is negligible when compared to the naturally occurring background radiation dose of approximately 350 millirem per year calculated in the surrounding communities and on the INEL, Reference 1. Operations at NRF did not result in any measurable radiation exposure to the general public. 


\section{TABLE 9 \\ SUMMARY OF CALCULATED RADIATION DOSE-TO-MAN FROM NRF OPERATIONS, CY 1993}

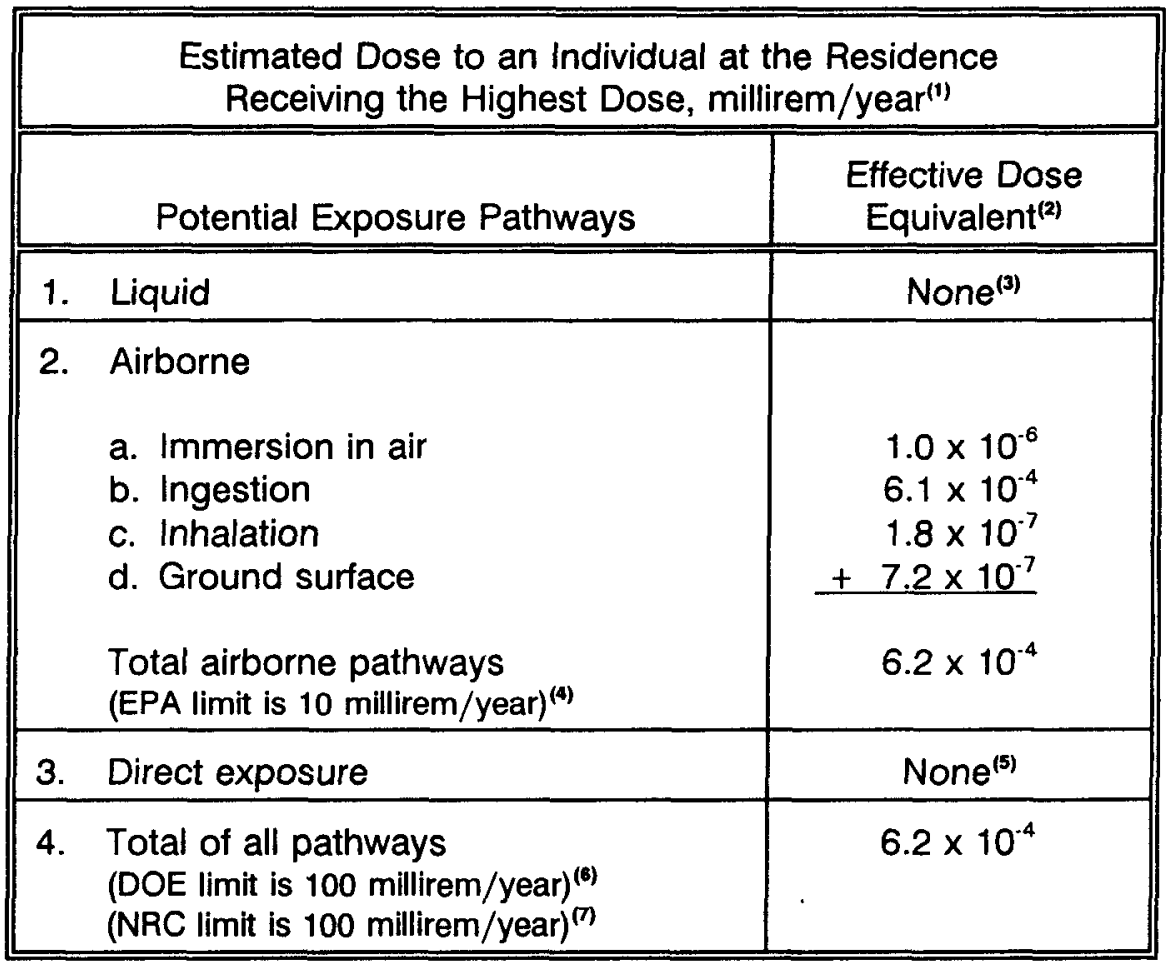

(1) The dose for the airborne pathways was calculated using the EPA approved CAP-88 computer model (Reference 6). Gross beta radioactivity was conservatively modeled as strontium- 90 with yttrium-90 progeny.

(2) Effective dose equivalent means the sum of the products of absorbed dose and appropriate factors to account for differences in biological effectiveness due to the quality of radiation and its distribution in the body of reference man. The unit for the effective dose equivalent is the rem. For purposes of this report, doses caused by naturally occurring radon-222 and its respective decay products are not included.

(3) NRF did not discharge any radioactivity from current operations to liquid effluent streams.

(4) As per Reference 7

(5) Because the radiation levels at the NRF site boundary are low, and the site is removed from public access, there is no exposure to the public from direct exposure pathways.

(6) As per Reference 8.

(7) As per Reference 9 


\section{CONTROL OF CHEMICAL AND HAZARDOUS WASTES}

\section{ORIGIN}

During 1993, the necessary use of hazardous materials at NRF resulted in the generation of some chemical and hazardous wastes. These wastes included photographic solutions, solutions containing heavy metals, organic solvents, paint related wastes, laboratory wastes, waste oils and wastes generated from prototype training activities.

\section{CONTROL PROGRAMS}

All hazardous wastes generated at NRF were managed in accordance with the Federal Resource Conservation and Recovery Act (RCRA) and the environmental regulations set forth by the State of Idaho. Nonhazardous chemical wastes were managed in accordance with applicable federal and state regulations.

The control programs assisted in the minimization of the quantity of routine waste material generated, assured safe usage and storage of the materials onsite and provided for proper disposal of wastes by vendors permitted by state and/or federal agencies.

A principal component of the overall control program was the review of purchase orders prior to the acquisition of chemicals at NRF. Purchase orders were reviewed to determine that the procurement of a hazardous material was necessary, to assure excessive quantities were not ordered and to determine if a suitable nonhazardous substitute was available. NRF also utilized a chemical exchange program which allowed groups onsite to exchange rather than purchase additional hazardous materials.

In 1992, a Chemical Management Program was developed, and a major revision to NRF's Waste Minimization/Pollution Preven- tion Program was completed. These programs provide additional controls for the use of hazardous materials and further reduce the generation of hazardous waste. The Chemical Management Program was designed to track and control the volume and use of hazardous material. This program additionally strengthens the control over procurement of hazardous materials. NRF's Waste Minimization/ Pollution Prevention Program provides a formal system to report amounts of waste generated, identifies waste streams to be reduced or eliminated, establishes waste minimization goals for generators, and provides for the issuance of progress reports on waste minimization efforts.

Appropriate training was provided to site personnel who handle hazardous materials to assure they are knowledgeable of safe handling techniques, emergency response procedures and the use of Material Safety Data Sheets. Personnel were also provided training on workers' Hazard Communication or Right-to-Know Standard as required under the Occupational Safety and Health Act.

Waste generated from the use of hazardous materials was accumulated and stored in approved areas. Hazardous waste was managed in accordance with federal and state hazardous waste regulations. Hazardous waste accumulation and storage areas were inspected routinely to verify that hazardous wastes were properly stored and controlled in accordance with approved work procedures and regulatory requirements. In addition, a compliance inspection was conducted at NRF by the State of Idaho in 1993. NRF was found to be in compliance with all applicable hazardous waste storage and handling regulations. 


\section{TREATMENT AND DISPOSAL PROGRAMS}

No hazardous wastes were disposed of at the NRF Site during 1993. Approximately 2,800 pounds of solid hazardous waste and 1,850 gallons of liquid hazardous waste were transported by contractors to EPA approved Treatment/Storage/Disposal (TSD) facilities. These amounts represent a 72 percent reduction in solid hazardous waste and a 39 percent reduction in liquid hazardous waste generated and transported off site compared to 1992 . The transportation vendors and the TSD facilities operate under approvals or permits granted by state and federal regulatory agencies.

NRF determines treatment and disposal methods in accordance with federal land disposal restrictions that reduce long term liabilities and endangerment to the public and the environment. When appropriate, wastes are recycled, burned for energy recovery purposes (e.g., waste oil) or neutralized prior to disposal.

In 1993, NRF recycled approximately 121 tons of hazardous waste in the form of lead and batteries. An additional 6,300 pounds of aluminum beverage containers were collected and recycled by Navy personnel. In addition, approximately 100 cubic feet of paper material was recycled.
Waste oil shipped offsite to be burned for energy recovery amounted to 5,823 gallons, and antifreeze recovered for recycling totaled 715 gallons.

Approximately 11,000 pounds of unneeded hazardous materials such as paints, sealants, adhesives, cleaning supplies, greases and other lubricants were transferred to other federal agencies. Scrap metal and wood totaling an estimated 978 cubic yards were also transferred from NRF to the INEL for storage and ultimately for recycling.

The use of elementary neutralization in the processing of corrosive wastewater has further reduced the volume of hazardous waste for disposal. Approximately 1.9 million gallons of ion exchange resin regeneration solution were processed to a nonhazardous form in 1993.

In 1993, all nonhazardous solid wastes were transported to the INEL landfills at the Central Facilities Area. 
CONTROL OF RADIOACTIVE WASTE

\section{MATERIALS}

\section{ORIGIN}

Operations at NRF during 1993 resulted in the generation of various types of low-level radioactive waste material. This material ranged from irradiated metal to paper and plastic products.

\section{CONTROL PROGRAM}

The volume of radioactive waste generated at NRF is minimized by work specific training programs, detailed work instructions, limitations of the amounts of material introduced to a radiological environment and volume reduction programs.

To facilitate the most effective means for disposal, radioactive waste was segregated into several categories: compactible, noncompactible, incinerable, and size-reducible. Where practicable, radioactive liquids were processed for reuse. Those liquids which could not be further processed were solid- ified prior to transport and disposal or placed into storage prior to incineration at the INEL's Waste Experimental Reduction Facility (WERF). Radioactive waste shipments were made in accordance with all applicable DOE and Department of Transportation (DOT) requirements.

\section{DISPOSAL}

All solid radioactive waste from NRF was shipped to either the Radioactive Waste Management Complex (RWMC) as noncompactible waste, or to the WERF for compaction, incineration, or size-reduction. After processing, WERF sends the final waste form to the RWMC for disposal. During 1993, approximately 17,038 cubic feet of solid radioactive waste containing 37,883 curies of radioactivity were shipped from NRF to these two radioactive material disposal facilities. 
This page intentionally left blank. 


\section{ENVIRONMENTAL AND EFFLUENT MONITORING QUALITY ASSURANCE}

NRF participates in an interlaboratory quality assurance program in cooperation with various vendor laboratories. This program was designed to test and demonstrate the consistency, continued precision and accuracy of laboratory techniques and results used by NRF to evaluate environmental data.

- Nonradiological: As prescribed by specific analytical methodology, subcontracted analytical laboratories demonstrated the precision and accuracy of the nonradiological analyses by properly analyzing quality control samples consisting of matrix spikes, duplicate samples, reagent blanks, surrogate compound spikes, and check samples. The vendor laboratories were not aware which samples were being used for quality control purposes. During 1993, all offsite subcontractor laboratories demonstrated satisfactory performance in sample quality control.

To demonstrate adequate control of the field sampling techniques during ground water sampling, trip blanks were collected and submitted for analysis. The results demonstrated satisfactory performance of field sampling techniques.

In addition, individual quality assurance programs practiced by subcontractor laboratories were reviewed and evaluated by chemists at NRF to ensure minimum standards were met per Reference 10.
- Radiological: To ensure and verify the quality of radiological data, samples submitted for analysis were subjected to quality assurance programs established by the DOE Radiological and Environmental Sciences Laboratory and the United States Geological Survey Laboratory. The programs consisted of the following key elements:

- personnel training and qualification

- detailed analytical procedures

- calibration of instrumentation

- American Society for Testing and Materials (ASTM) test sample rotation

- participation in an intercomparison program

- use of blind controls

- participation in analysis of calibration standards

The NRF Chemistry Laboratory performs radiological measurements of soil, vegetation, water and air samples at NRF. This Laboratory participates in the U.S. EPA Performance Evaluation Studies Program and the U.S. DOE Environmental Measurements Laboratory Quality Assessment Program. Results of these interlaboratory cross check programs are presented in Appendix $D$ and $E$ respectively.

The interlaboratory quality assurance program in conjunction with existing NRF analytical quality assurance practices provided for the validation of data to ensure accuracy in the radiological environmental monitoring program. 
This page intentionally left blank. 


\section{REFERENCES}

(1) The Idaho National Engineering Laboratory Site Environmental Report for Calendar Year 1992, DOE/ID-12082(92), June 1993.

(2) Title 1, Chapter 8, Idaho Regulations for Public Drinking Water Systems.

(3) AP-42, Compilation of Air Pollutant Emission Factors, Volume I: Stationary Point and Area Sources, Fourth Edition, Table 1.3-1.

(4) Idaho Department of Health and Welfare Rules, Title 1, Chapter 1, "Rules for the Control of Air Pollution in Idaho."

(5) Code of Federal Regulations, Title 40 Part 50.

(6) Clean Air Act Assessment Package - 1988 (CAP-88) - A Dose and Risk Assessment Methodology for Radionuclide Emissions to Air, September 1989.

(7) Code of Federal Regulations, Title 40 Part 61, Subpart $\mathrm{H}$.

(8) DOE Order 5400.5, Radiation Protection of the Public and Environment.

(9) Code of Federal Regulations, Title 10 Part 20, Section 1301.

(10) U. S. Environmental Protection Agency, "Test Methods for Evaluating Solid Waste, Physical/Chemical Methods", SW 846, current edition. 
This page intentionally left blank. 
APPENDIX A

LIQUID EFFLUENT ORGANIC ANALYTES

\begin{tabular}{|c|c|c|}
\hline $\begin{array}{l}\text { SEMH-VOLATILE ORGANIC COMPOUNDS } \\
\text { Acenaphthene } \\
\text { Acenaphthylene } \\
\text { Aniline } \\
\text { Anthracene } \\
\text { Benzo (a) anthracene } \\
\text { Benzo (b) fluoranthene } \\
\text { Benzo (k) fluoranthene } \\
\text { Benzo (g,h,l) perylene } \\
\text { Benzo (a) pyrene } \\
\text { Benzyl alcohol } \\
\text { bis (2-chloroethoxy) methane } \\
\text { bis (2-chloroethyl) ether } \\
\text { bis (2-chloroisopropyl) ether } \\
\text { bis (2-ethylhexyl) phthalate } \\
\text { 4-Bromophenyl phenyl ether } \\
\text { Butyl benzyl phthalate } \\
\text { 4-Chloroaniline } \\
\text { 2-Chloronaphthalene } \\
\text { 4-Chloro-3-methylphenol } \\
\text { 2-Chlorophenol } \\
\text { 4-Chlorophenyl phenyl ether } \\
\text { Chrysene } \\
\text { Dibenzo (a,h) anthracene } \\
\text { Dibenzofuran } \\
\text { Di-n-butylphthalate } \\
\text { 1,2-Dichlorobenzene } \\
\text { 1,3-Dichlorobenzene } \\
\text { 1,4-Dichlorobenzene } \\
\text { 3,3-Dichlorobenzidine } \\
\text { 2,4-Dichlorophenol } \\
\text { Diethylphthalate } \\
\text { 2,4-Dimethylphenol } \\
\text { Dimethylphthalate } \\
\text { 4,6-Dinitro-2-methylphenol } \\
\text { 2,4-Dinitrophenol } \\
\text { 2,4-Dinitrotoluene } \\
\text { 2,6-Dinitrotoluene } \\
\text { Di-n-octylphthalate } \\
\text { Fluoranthene } \\
\text { Fuorene } \\
\text { Hexachlorobenzene } \\
\text { Hexachlorobutadiene } \\
\text { Hexachlorocyclopentadiene } \\
\text { Hexachloroethane } \\
\text { Indeno (1,2 3-cd) pyrene } \\
\text { Isophorone } \\
\text { 2-Methylnaphthalene } \\
\text { 2-Methylphenol (o-cresol) } \\
\text { 4-Methylphenol (p-cresol) } \\
\text { Naphthalene } \\
\text { 2-Nitroaniline } \\
\text { 3-Nitroaniline } \\
\text { 4-Nitroaniline }\end{array}$ & $\begin{array}{l}\text { Nitrobenzene } \\
\text { 2-Nitrophenol } \\
\text { 4-Nitrophenol } \\
\text { N-Nitrosodimethylamine } \\
\text { N-Nitrosodiphenylamine } \\
\text { N-Nitrosodipropylamine } \\
\text { Pentachlorophenol } \\
\text { Phenanthrene } \\
\text { Phenol } \\
\text { Pyrene } \\
\text { 1,2,4-Trichlorobenzene } \\
\text { 2,4,5-Trichlorophenol } \\
\text { 2,4,6-Trichlorophenol } \\
\text { voLATILE ORGANiC COMPOUNDS } \\
\text { Acetone } \\
\text { Acrolein } \\
\text { Acrylonitrile } \\
\text { Benzene } \\
\text { Bromodichloromethane } \\
\text { Bromoform } \\
\text { Bromomethane } \\
\text { Carbon disulfide } \\
\text { Carbon tetrachloride } \\
\text { Chlorobenzene } \\
\text { Chlorodibromomethane } \\
\text { Chloroethane } \\
\text { Chloroform } \\
\text { Chloromethane } \\
\text { 1,1-Dichloroethane } \\
\text { 1,2-Dichloroethane } \\
\text { 1,1-Dichloroethene } \\
\text { 1,2-Dichloroethene (total) } \\
\text { 1,2-Dichloropropane } \\
\text { cis-1,3-Dichloropropene } \\
\text { trans-1,3-Dichloropropene } \\
\text { Ethylbenzene } \\
\text { 2-Hexanone } \\
\text { 4-Methyl-2-pentanone } \\
\text { Methylene Chloride } \\
\text { Methyl Ethyl Ketone } \\
\text { Styrene } \\
\text { 1,1,2,2-Tetrachloroethane } \\
\text { Tetrachloroethene } \\
\text { Toluene } \\
\text { 1,1,1-Trichloroethane } \\
\text { 1,1,2-Trichloroethane } \\
\text { Trichloroethene } \\
\text { Trichlorofluoromethane } \\
\text { Vinyl acetate } \\
\text { Vinyl chloride } \\
\text { Xylenes, (total) }\end{array}$ & 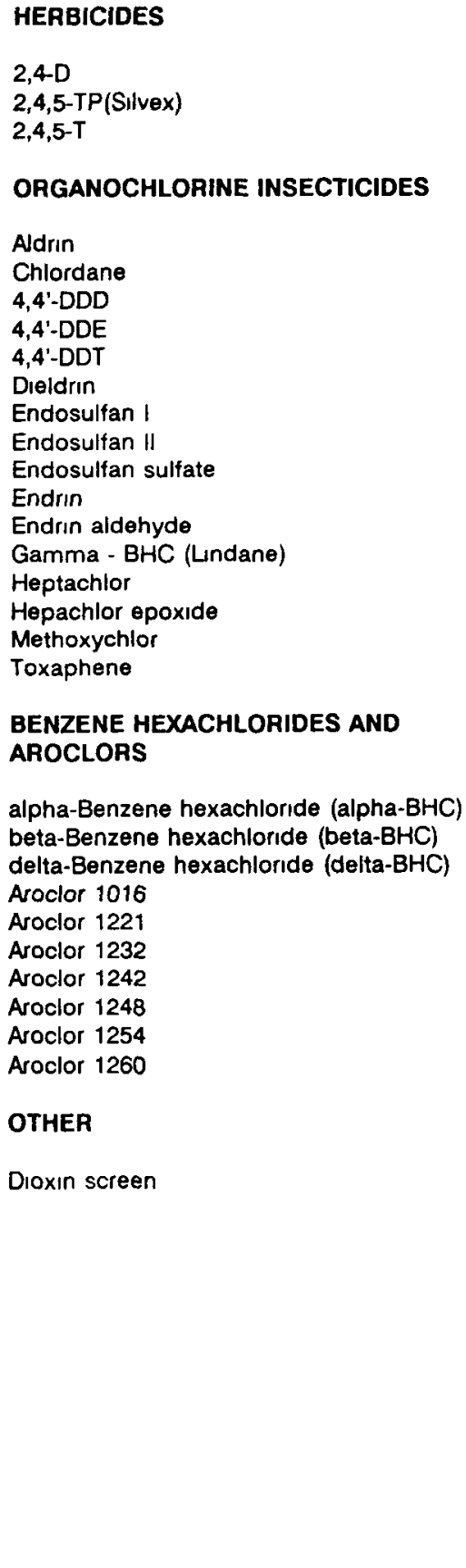 \\
\hline
\end{tabular}


This page intentionally left blank. 
APPENDIX B

NRF DRINKING WATER SYSTEM VOLATILE ORGANIC CHEMICAL (VOC) ANALYTES

\begin{tabular}{|c|c|c|}
\hline REGULATED VOCs ${ }^{(1)}$ & $\begin{array}{c}\text { Maximum Allowable } \\
\text { Contaminant Level } \\
\qquad \mu g / 1\}^{(2)}\end{array}$ & UNREGULATED VOCs ${ }^{|3|}$ \\
\hline $\begin{array}{l}\text { Benzene } \\
\text { Carbon tetrachloride } \\
\text { Chlorobenzene } \\
\text { o-Dichlorobenzene } \\
\text { p-Dichlorobenzene } \\
\text { 1,2-Dichloroethane } \\
\text { 1,1-Dichloroethene } \\
\text { cis-1,2-Dichloroethene } \\
\text { trans-1,2 Dichloroethene } \\
\text { Dichloromethane } \\
\text { 1,2-Dichloropropane } \\
\text { Ethylbenzene } \\
\text { Styrene } \\
\text { Tetrachloroethene } \\
\text { Toluene } \\
\text { 1,2,4-Trichlorobenzene } \\
\text { 1,1,1-Trichloroethane } \\
\text { 1,1,2-Trichloroethane } \\
\text { Trichloroethene } \\
\text { Vinyl chloride } \\
\text { Xylenes (total) }\end{array}$ & $\begin{array}{c}5 \\
5 \\
100 \\
600 \\
75 \\
5 \\
7 \\
70 \\
100 \\
5 \\
5 \\
700 \\
100 \\
5 \\
1,000 \\
70 \\
200 \\
5 \\
5 \\
2 \\
10,000\end{array}$ & $\begin{array}{l}\text { Bromobenzene } \\
\text { Bromodichloromethane } \\
\text { Bromoform } \\
\text { Bromomethane } \\
\text { Chlorodibromomethane } \\
\text { Chloroethane } \\
\text { Chloroform } \\
\text { Chloromethane } \\
\text { o-Chlorotoluene } \\
\text { p-Chlorotoluene } \\
\text { m-Dichlorobenzene } \\
\text { 1,1-Dichloroethane } \\
\text { 1,3-Dichloropropane } \\
\text { 2,2-Dichloropropane } \\
\text { 1,1-Dichloropropene } \\
\text { cis-1,3-Dichloropropene } \\
\text { trans-1,3-Dichloropropene } \\
\text { 1,1,1,2-Tetrachloroethane } \\
\text { 1,1,2,2-Tetrachloroethane } \\
\text { 1,2,3-Trichloropropane } \\
\text { OTHER } \\
\text { Bromochloromethane } \\
\text { n-Butylbenzene } \\
\text { sec-Butylbenzene } \\
\text { tert-Butylbenzene } \\
\text { Dibromomethane } \\
\text { Dichlorodifluoromethane } \\
\text { Hexachlorobutadiene } \\
\text { Isopropylbenzene } \\
\text { p-Isopropyltoluene } \\
\text { Naphthalene } \\
\text { n-Propylbenzene } \\
\text { 1,2,3-Trichlorobenzene } \\
\text { Trichlorofluoromethane } \\
\text { 1,2,4-Trimethylbenzene } \\
\text { 1,3,5-Trimethylbenzene } \\
\text { m-Xylene } \\
\text { o-Xylene } \\
\text { p-Xylene }\end{array}$ \\
\hline
\end{tabular}

(1) Regulated VOCs are organic compounds for which a maximum allowable contaminant level has been established under the State of Idaho and Federal Drinking Water Regulations.

(2) Per 40 CFR 141.61, Subpart G.

(3) Unregulated VOCs are organic compounds which must be analyzed, but have no associated maximum allowable contaminant level under the State of ldaho and Federal Drinking Water Regulations. VOCs termed "Other" are not required analytes under current regulations. These analytes, however, were not found at drinking water method detection limits and are listed for information only. 
This page intentionally left blank. 


\section{APPENDIX C}

NRF DRINKING WATER SYSTEM SYNTHETIC ORGANIC CHEMICAL (SOC) ANALYTES

\begin{tabular}{|c|c|c|}
\hline REGULATED SOCs ${ }^{(1)}$ & $\begin{array}{c}\text { Maximum Allowable } \\
\text { Contaminant Level } \\
\{\mu g / 1\}^{(2)}\end{array}$ & UNREGULATED SOCs $s^{(3)}$ \\
\hline $\begin{array}{l}\text { Alachlor } \\
\text { Aldicarb } \\
\text { Aldicarb Sulfone } \\
\text { Aldicarb Sulfoxide } \\
\text { Atrazine } \\
\text { Benzo[a]pyrene } \\
\text { Carbofuran } \\
\text { Chlordane } \\
\text { 2,4-D } \\
\text { Dalapon } \\
\text { 1,2-Dibromo3-chloropropane } \\
\text { 1,2-Dibromoethane } \\
\text { Di[2-Ethylhexyl]-adipate } \\
\text { Di[2-Ethylhexyl]-phthalate } \\
\text { Dinoseb } \\
\text { Dioxin (2,3,7,8-TCDD) } \\
\text { Diquat } \\
\text { Endothall } \\
\text { Endrin } \\
\text { Glyphosate } \\
\text { Heptachlor } \\
\text { Heptachlor epoxide } \\
\text { Hexachlorobenzene } \\
\text { Hexachlorocyclopentadiene } \\
\text { Lindane } \\
\text { Methoxychlor } \\
\text { Oxamyl (Vydate) } \\
\text { PCB's } \\
\text { Pentachlorophenol } \\
\text { Picloram } \\
\text { Simazine } \\
\text { Toxaphene } \\
\text { 2,4,5-TP (Silvex) }\end{array}$ & $\begin{array}{c}2 \\
3 \\
3 \\
4 \\
3 \\
0.2 \\
40 \\
2 \\
70 \\
200 \\
0.2 \\
0.05 \\
400 \\
6 \\
7 \\
3 \times 10^{-5} \\
20 \\
100 \\
2 \\
700 \\
0.4 \\
0.2 \\
1 \\
50 \\
0.2 \\
40 \\
200 \\
0.5 \\
1 \\
500 \\
4 \\
3 \\
50\end{array}$ & $\begin{array}{l}\text { Aldrin } \\
\text { Butachlor } \\
\text { Carbaryl } \\
\text { Dicamba } \\
\text { Dieldrin } \\
\text { 3-Hydroxycarbofuran } \\
\text { Methomyl } \\
\text { Metolachlor } \\
\text { Metribuzin } \\
\text { Propachlor } \\
\text { OTHER } \\
\text { Acenaphthene } \\
\text { Acifluoren } \\
\text { Anthracene } \\
\text { Bentazon } \\
\text { Benzo (a) anthracene } \\
\text { Benzo (b) fluoranthene } \\
\text { Benzo (k) fluoranthene } \\
\text { Benzo (g,h,i) perylene } \\
\text { Butylbenzylphthalate } \\
\text { Chloramben } \\
\text { Chrysene } \\
\text { Dacthal } \\
\text { 2,4-DB } \\
\text { Dibenzo (a,h) anthracene } \\
\text { Dichlorprop } \\
\text { Diethylphthalate } \\
\text { Di-n-butylphthalate } \\
\text { Fluorene } \\
\text { Indeno (1,2,3,c,d) pyrene } \\
\text { Phenanthrene } \\
\text { Pyrene } \\
24,5-T\end{array}$ \\
\hline
\end{tabular}

(1) Regulated SOCs are organic compounds for which a maximum allowable contaminant level has been established under the State of Idaho and Federal Drinking Water Regulations.

(2) Per 40 CFR 141.61, Subpart G.

(3) Unregulated SOCs are organic compounds which must be analyzed, but have no associated maximum allowable contaminant level under the State of Idaho and Federal Drinking Water Regulations. SOCs termed "Other" are not required analytes under current regulations. These analytes, however, were not found at drinking water method detection limits and are listed for information only. 
This page intentionally left blank. 
APPENDIX D

1993 USEPA Cross Check Chemistry Results for NRF Chemistry Laboratory

\begin{tabular}{|c|c|c|c|c|c|c|c|}
\hline DATE & MEDIUM & ATTRIBUTE ${ }^{11}$ & UNITS & $\begin{array}{c}\text { REPORTED } \\
\text { VALUE }^{(2)}\end{array}$ & $\begin{array}{l}\text { KNOWN } \\
\text { VALUE }\end{array}$ & ND $(X \sigma)^{(3)}$ & NOTE \\
\hline Jun93 & water & $\begin{array}{l}\text { Co-60 } \\
\text { Zn-65 } \\
\text { Ru-106 } \\
\text { Cs-134 } \\
\text { Cs-137 } \\
\text { Ba-133 }\end{array}$ & $\mathrm{pCi} /$ liter & $\begin{array}{c}14.00 \\
103.00 \\
98.00 \\
5.00 \\
6.33 \\
87.33\end{array}$ & $\begin{aligned} 15.0 & \pm 5.0 \\
103.0 & \pm 10.0 \\
119.0 & \pm 12.0 \\
5.0 & \pm 5.0 \\
5.0 & \pm 5.0 \\
99.0 & \pm 10.0\end{aligned}$ & $\begin{array}{c}-0.35 \\
0.00 \\
-3.03 \\
(0) \\
0.46 \\
-2.02\end{array}$ & (4) \\
\hline Aug93 & air filter & $\begin{array}{c}\text { Gross alpha } \\
\text { Gross beta } \\
\text { Cs-137 }\end{array}$ & $\mathrm{pCi} /$ filter & $\begin{array}{l}21.33 \\
52.67 \\
10.00\end{array}$ & $\begin{array}{c}19.0 \pm 5.0 \\
47.0 \pm 5.0 \\
9.0 \pm 5.0\end{array}$ & $\begin{array}{l}0.81 \\
1.96 \\
0.35\end{array}$ & \\
\hline Nov93 & water & $\begin{array}{l}\text { Co-60 } \\
\text { Zn-65 } \\
\text { Ru-106 } \\
\text { Cs-134 } \\
\text { Cs-137 } \\
\text { Ba-133 }\end{array}$ & $\mathrm{pCi} /$ liter & $\begin{array}{c}28.67 \\
156.33 \\
170.33 \\
55.00 \\
38.00 \\
69.33\end{array}$ & $\begin{aligned} 30.0 & \pm 5.0 \\
150.0 & \pm 15.0 \\
201.0 & \pm 20.0 \\
59.0 & \pm 8.0 \\
40.0 & \pm 5.0 \\
79.0 & \pm 5.0\end{aligned}$ & $\begin{array}{l}-0.46 \\
0.73 \\
-2.66 \\
-1.39 \\
-0.69 \\
-2.09\end{array}$ & \\
\hline
\end{tabular}

Quantitative gamma analysis unless otherwise stated.

Reported value is the average of a triplicate set.

Normalized deviation from the known as described in EPA-600/7-77-068 dated August, 1977.

Values $-3>\mathrm{ND}>+3$ require corrective action.

The result for Ru-106 was outside the $\pm 3 \sigma$ control limit. The EPA is currently providing water samples with extremely low levels of Ru-106 activity. The Ru-106 daughter nuclide decays with a gamma ray abundance of only $9.8 \%$ at an energy of $622 \mathrm{KeV}$, making this nuclide difficult to quantify at low levels. Subsequent measurements of this nuclide were closely monitored for accuracy. The reported Ru-106 activity for the Nov93 sample was within the acceptable range. 
This page intentionally left blank. 


\section{APPENDIX E}

1993 USDOE Cross Check Chemistry Results for NRF Chemistry Laboratory

\begin{tabular}{|c|c|c|c|c|c|c|c|}
\hline DATE & MEDIUM & ATTRIBUTE ${ }^{(1)}$ & UNTS & $\begin{array}{c}\text { REPORTED } \\
\text { VALUE }\end{array}$ & $\begin{array}{l}\text { KNOWN } \\
\text { VALUE }\end{array}$ & $N D(X \sigma)^{(2)}$ & NOTE \\
\hline 9309 & soil & $\begin{array}{c}\text { K-40 } \\
\text { Cs-137 }\end{array}$ & $\mathrm{Bq} / \mathrm{kg}$ & $\begin{array}{l}30 \pm 5 \\
11 \pm 1\end{array}$ & $\begin{array}{l}28.6 \\
11.4\end{array}$ & $\begin{array}{c}0.5 \\
-0.4\end{array}$ & \\
\hline 9309 & vegetation & $\begin{array}{c}K-40 \\
\text { Co-60 } \\
\text { Cs-137 }\end{array}$ & $\mathrm{Bq} / \mathrm{kg}$ & $\begin{array}{c}1050 \pm 37 \\
7 \pm 2 \\
102 \pm 3\end{array}$ & $\begin{array}{l}842 \\
6.45 \\
89.2\end{array}$ & $\begin{array}{l}2.5 \\
0.9 \\
1.4\end{array}$ & \\
\hline
\end{tabular}

(11) Quantitative gamma analysis.

(2) Normalized deviation from the known as described in EML-454 dated May 1, 1986.

Values $-3>N D>+3$ require corrective action. 
This page intentionally left blank. 


\section{DISTRIBUTION}

Honorable Larry E. Craig

U S Senate

Washington D C 20032

Honorable Michael Crapo

US House of Representatives

Washington D C 20018

\section{Orville Green}

Permits and Enforcement Division Division of Environmental Quality Idaho Department of Health and Welfare 1410 North Hilton

Boise, Idaho 83706

\section{$\checkmark$ L. Harris}

Idaho Department of Health and Welfare 1410 North Hilton

Bolse, Idaho 83706

\section{Brett Hayball}

Shoshone-Bannock Tribes

PO Box 306

Fort Hall, Idaho 83203

\section{Steve Hill \\ INEL Oversight Program \\ Idaho Department of Health and Welfare 1410 North Hilton}

Bosse, Idaho 83706

\section{Honorable Dirk Kempthorne}

\section{U S Senate}

Washıngton D C 20032

\section{Honorable Larry LaRocco}

US House of Representatives

Washıngton DC 20018

\section{John Ledger}

Planning and Evaluation Division Division of Environmental Quality Idaho Department of Health and Welfare 1410 North Hilton

Boise, Idaho 83706

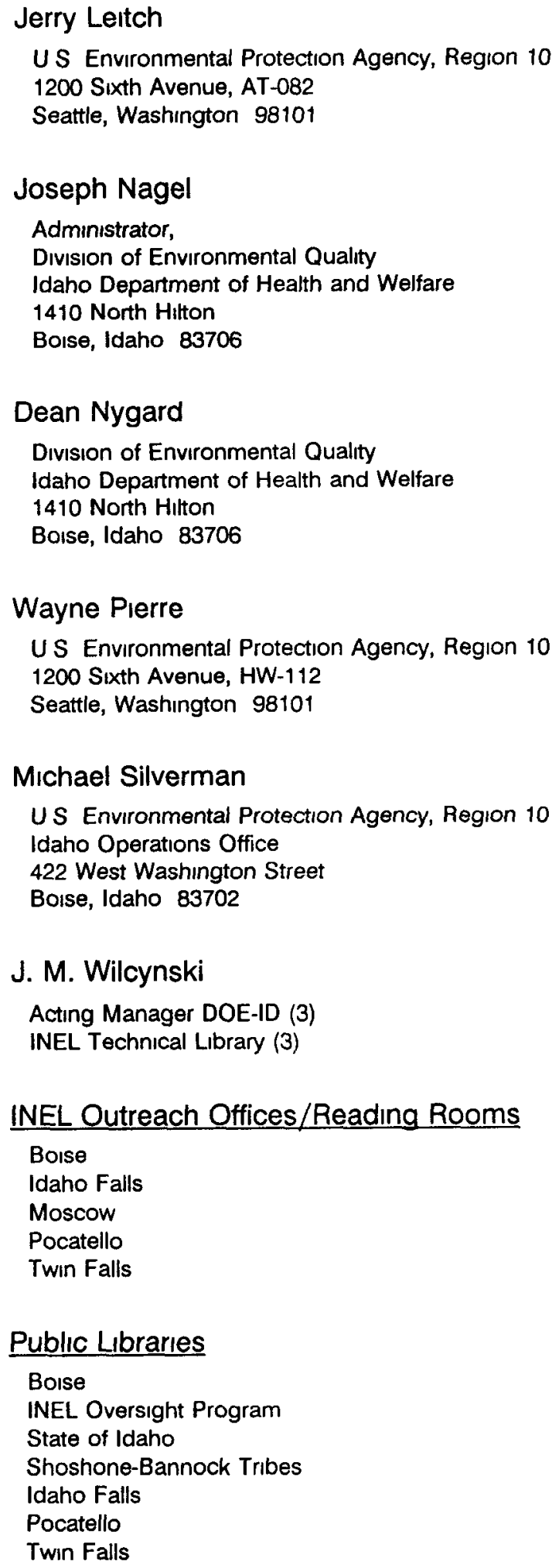

\section{J. M. Wilcynski}

Actıng Manager DOE-ID (3)

INEL Technical Library (3)

\section{INEL Outreach Offices/Reading Rooms}

\section{Public Libraries}

Boise

INEL Oversight Program

State of Idaho

Shoshone-Bannock Tribes

Idaho Falls

Pocatello

Twin Falls 